
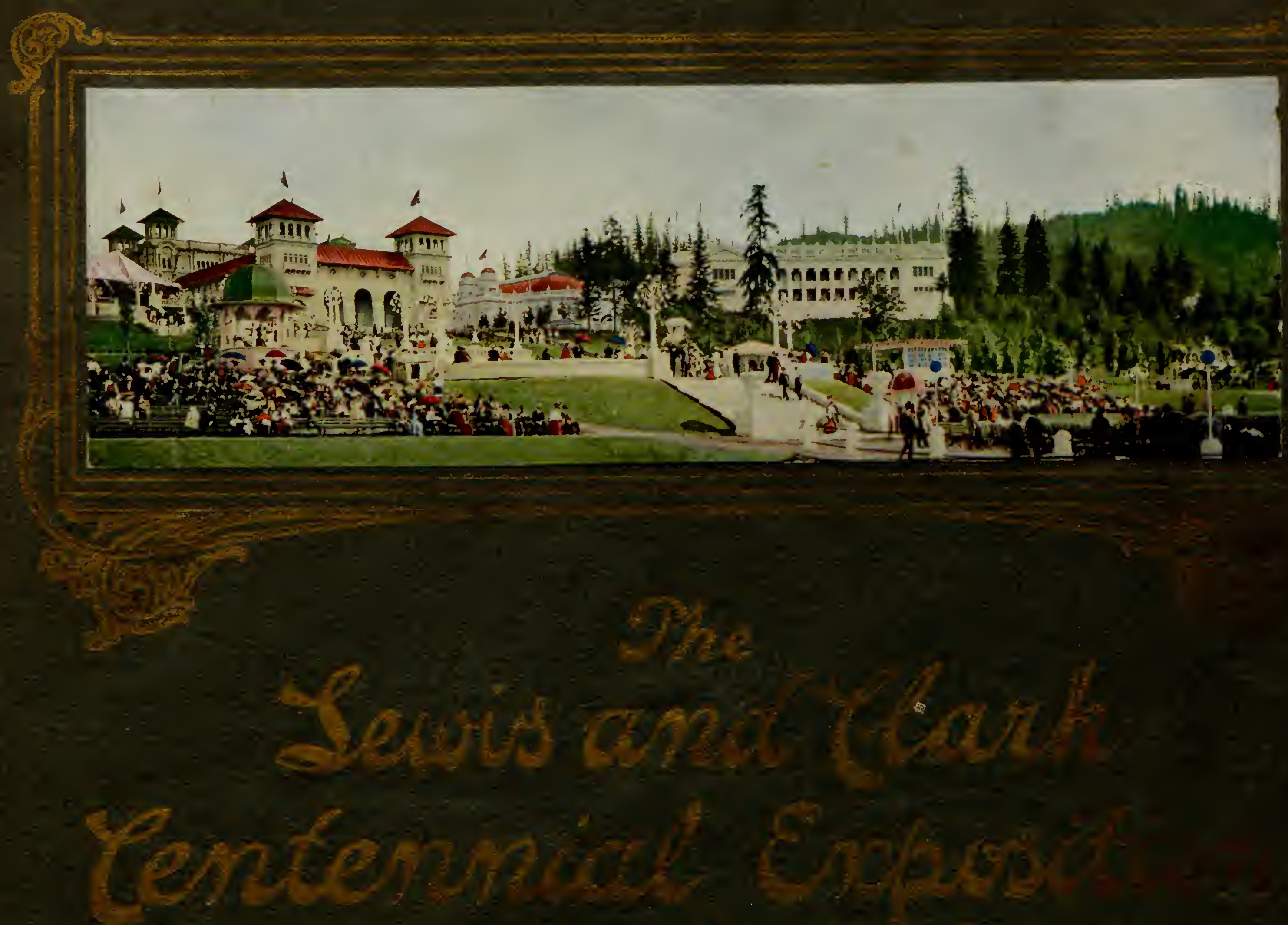


\section{The Lewis and Clark Centennial Exposition Illustrated}

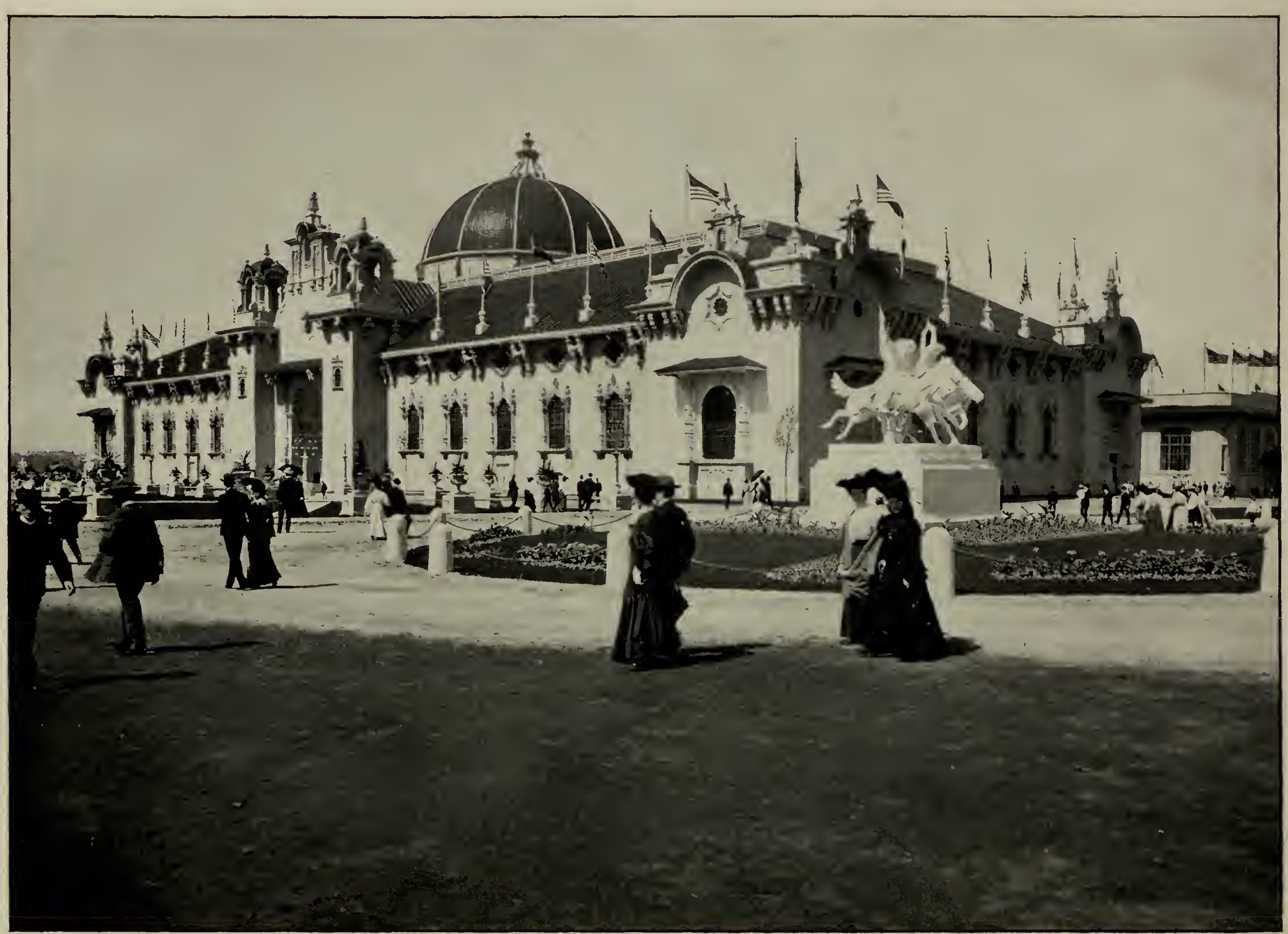

the agricultural palace

Robert allan Reid, Publisher, Portland, Oregon 1905 


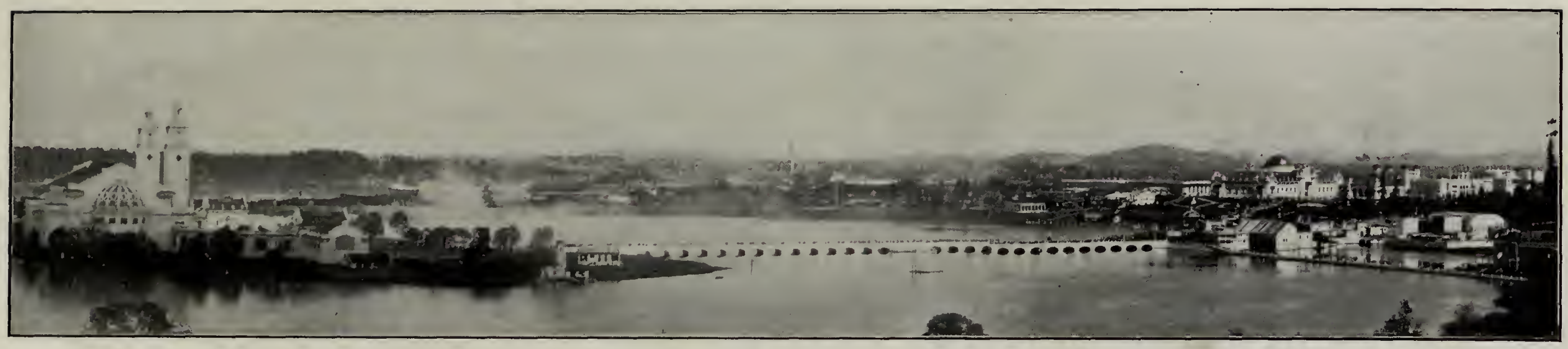

A VIEW OF THE EXPOSITION FROM WILLAMETTE HEIGHTS, SHOWING THE LAKE FRONT AND BRIDGE OF NATIONS

\section{THE LEWIS AND CLARK EXPOSITION}

The progress of the people of the American Nation is the marvel of the whole world. The broadening of intelligence, the advancement of discovery, inventions, science, agriculture and all the useful arts and industries which has taken place, within the last hundred years, has placed our country in a position which is rapidly becoming the most commanding among the nations of the earth. To emphasize the great importance in our nation's life and progress of the explorations of Lewis and Clark, and the consequent addition to the United States of the Oregon Country there has here arisen almost as by magic, this magnificent creation-the Lewis and Clark Exposition.

The people from many lands and from all parts of our own country have been bidden to help observe this Centennial Anniversary - to note the progress and to be inspired by evidences of past achievement.

Upon arrival at the Exposition grounds, the visitor passes through the Colonnade entrance and Pacific Court to Lake View Terrace. Here are spread before him undreamed of scenes of beauty. Wide stretches of lake and river lie in the distance, with the Government Buildings, grand and imposing, forming the further border of the picture. On the left rise majestically the fir-covered Willamette Heights, and other forest-covered hills of Oregon. To the right is the Willamette River, and far beyond are the eternally snow-capped peaks of Mt. Hood, Mt. Adams and Mt. St. Helens. Below are shelving terraces, the Rose Gardens, the Grand Stairway, the Band Stand and Guilds Lake, with fairy boats skimming over its waters. Nearby is a group of beautiful State Buildings, while away to the left is the Trail, the aggregation of amusement enterprises. From the Trail extends the Bridge of Nations, leading to the Government Buildings. To Lake View Terrace the visitor should return at night when the electric illuminations transform the entire picture into new forms of grandeur and beauty.

After a survey of the grounds the visitor may begin upon the pleasures of sight-seeing or the study of the exhibits, as fancy may dictate. Gathered as they are, from the four corners of the earth, the displays have something new for all. The visitor of a day may hastily glance through the palaces of exhibits and be impressed by the wide variety and splendor, but the leisurely visitor, with studious bent, is the one who will gather new treasures of knowledge which are to be found on every hand.

A Souvenir - a pleasant reminder-of happy hours spent at the beautiful Lewis and Clark Centennial Exposition may these pictures be, to all who have been fortunate enough to be visitors! A help to a knowledge of the attractions of the Exposition of "1905" may they be to all others! 


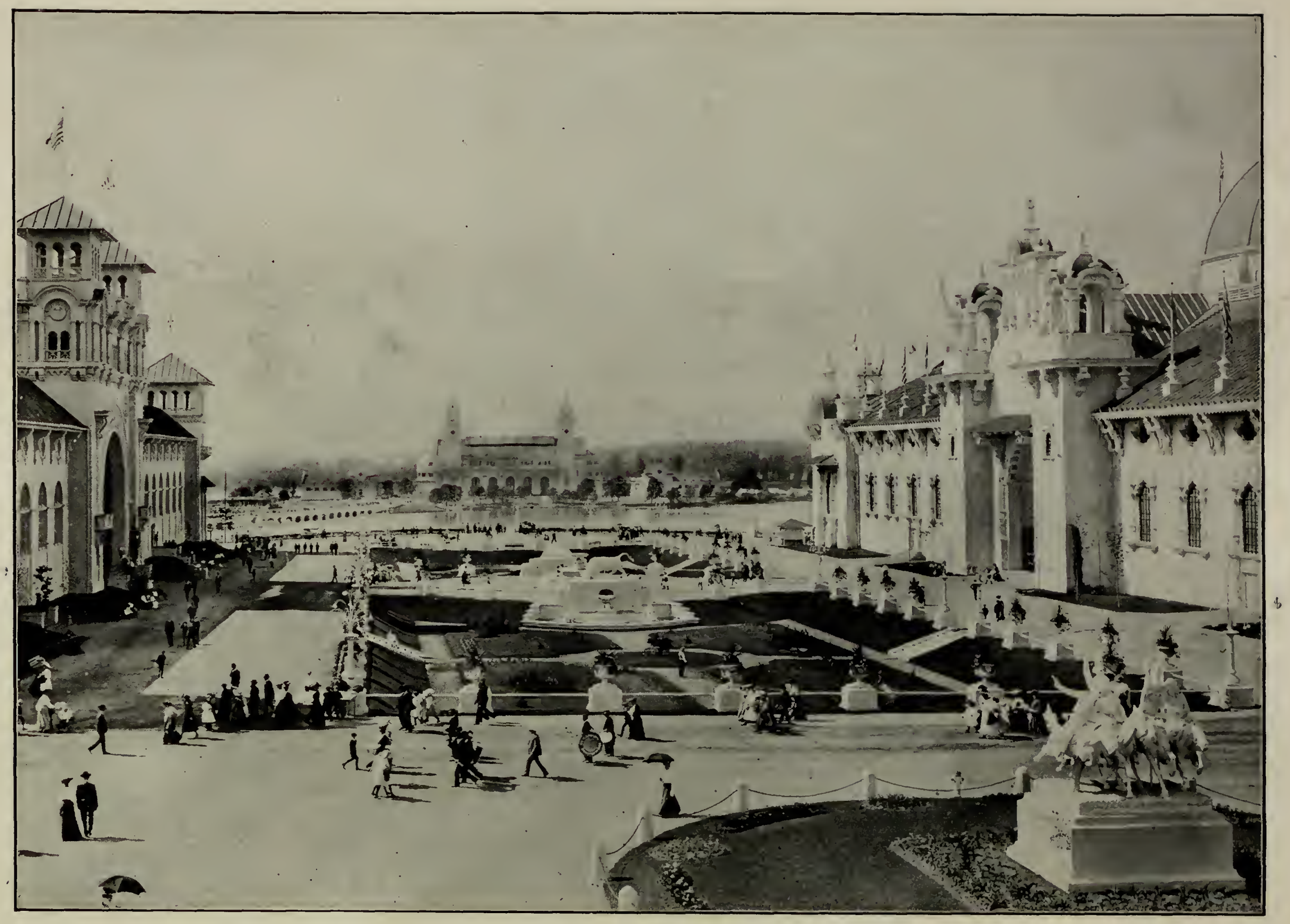

THE SUNKEN GARDENS

The Sunken Gardens are located in the spaee between the Palaces of Agriculture and Oriental Fxhibits. "At one end is I,ewis and Clark Arenue, upon which is situated the stirring group of statuary, Hitting the Trail, or "The Cowboys Shooting Up the Town," At the further end is Lake View Terrace,

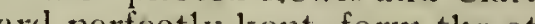
tractions of the gardens themselves, the beauty of all being greatly enhaneed by the lighting of the gracefully formed electrie lamps borlering the grounds. 


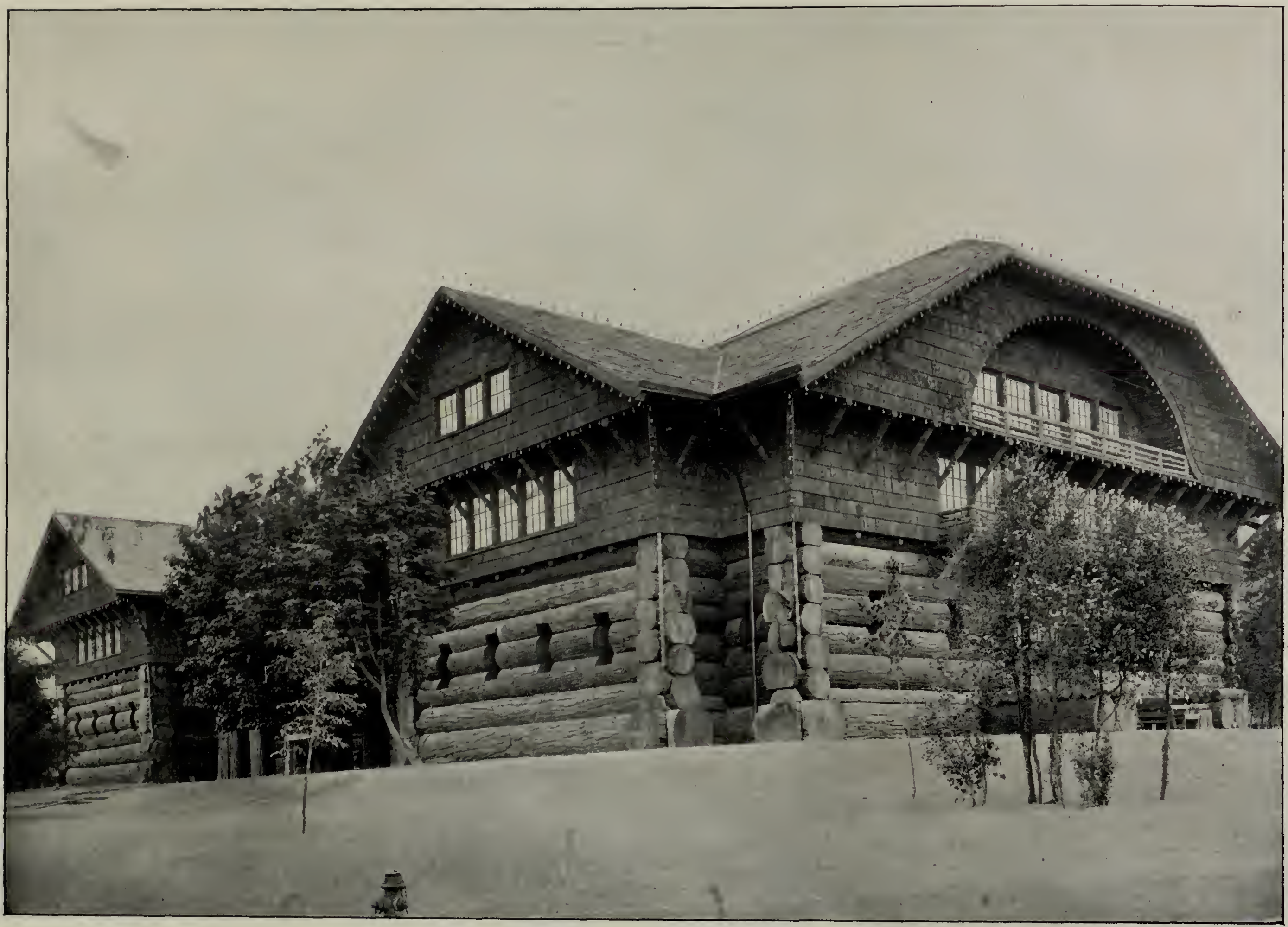

FORESTRY BUILDING The Forestry Building is constructed of great unlewn logs of the forest. It is 100 feet wide and 200 feet long, and was designed by Ion Lewis, architect, of
Portlant. The great size of the log building. the inmense dinensions of the logs thserl in its construction, many being six feet in dianneter, and 60 feet long. and the originality show1 in thus representing one of Oregon's greatest ind ustries, makes the Forestry Building the most remarkable of any of the exhibit structures at the Exposition. Within the Forestry Building are sanples of woods from the forests of Oregon, the most noticeable being planks nine feet wide, working models and

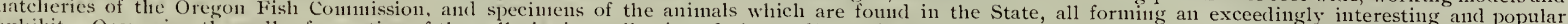

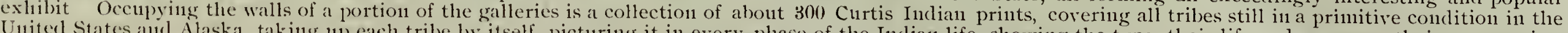
and the 


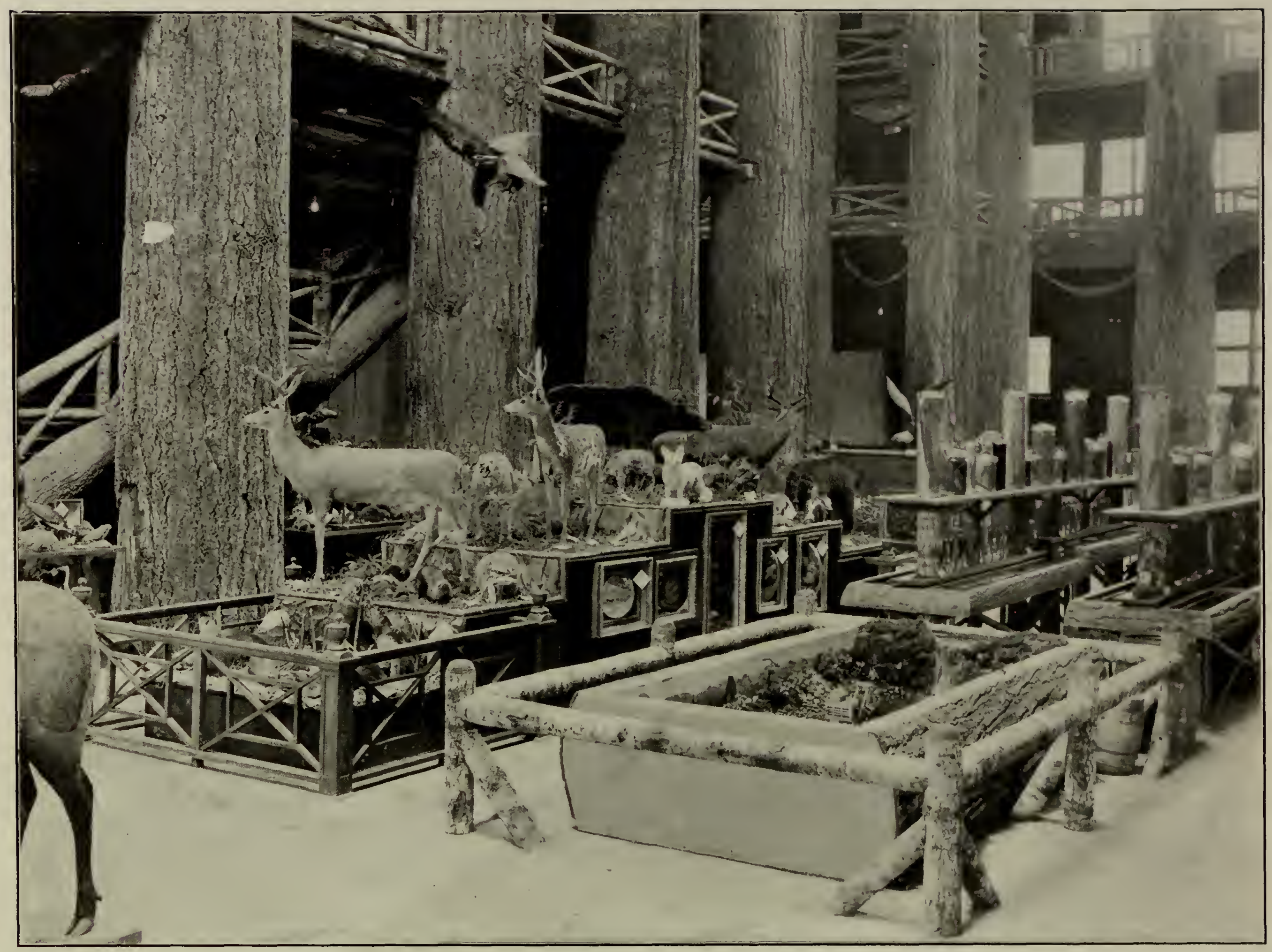

INTERIOR OF FORESTRY BUILDING.

Very little in the way of decoration was required in the Forestry. Building to make it attractive. The interior, like the outside, lepends upon its simplicity and the great size of the unhewn logs for its impressive effect upon visitors. A few rustic railings are set hetween the logs, done in the best of taste, but onle feels that nature has amply provided the materials of so striking a character, that the skill of man could do little more than place her products in orderly position. So

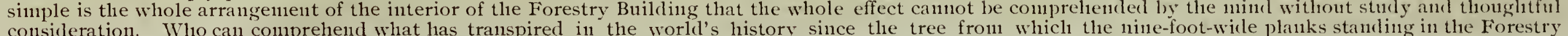
Buildling were hew11 was a sapling? Every one goes to the Forestry Building. It is not second among the great successes of the Fair. 


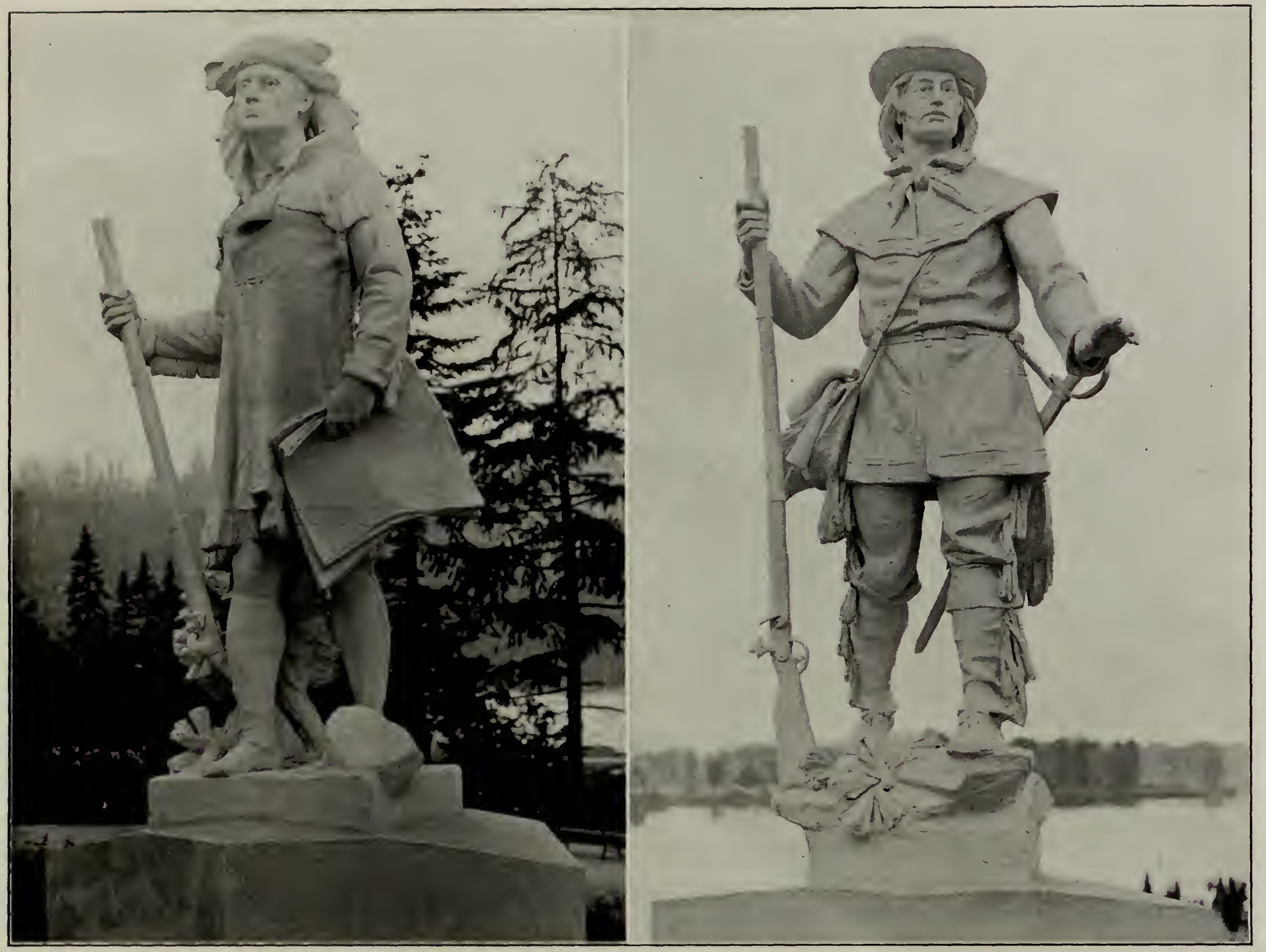

STATUE OF CAPTAIN MERIWETHER LEWIS

STATUE OF CAPTAIN WILLIAM CLARK

Captain Meriwether Lewis was born in Virginia, Augnst 18, 1774. At the age of twenty he volunteered to assist in suppressing the "Whiskey Insurrection.". He was appointed ensign in the army in 1795 . In 1797 he was promoted to a captaincy, and appointed private secretary by President Jefferson in 1801 . Early in 1803 he was selected by the presilent to lead the exploring expedition to the Pacific Coast. After returning to St. Louis, he resigned his conunission on March ", 1807 , and the next dav was appointed Governor of Lonisiana Territory. While on a tour in comection with his official duties he died on October 11, 1809, in Temnessee, Captain Willian Clark was horn in Virginia August 1, 1770. He was appointed ensign, U. S. A., 1788, and captain of militia, N. W. Territory, January 8, 1790; hententint in U. S. infantry, 1791; resigned on account of in health on July 1, 1796. He re-entered the army, as second lieutenant of artillery March 26, 1804; resigned on Teloruary 27. 1807, and was appointed brigadier-general for Louisiana Territory, March 12, 1807; was appointed Goveruor of Missouri July 1 , 183 , and held the position mitil 1820 , and muncrous other federal positions up to the date of his death, September 1,1838 . 


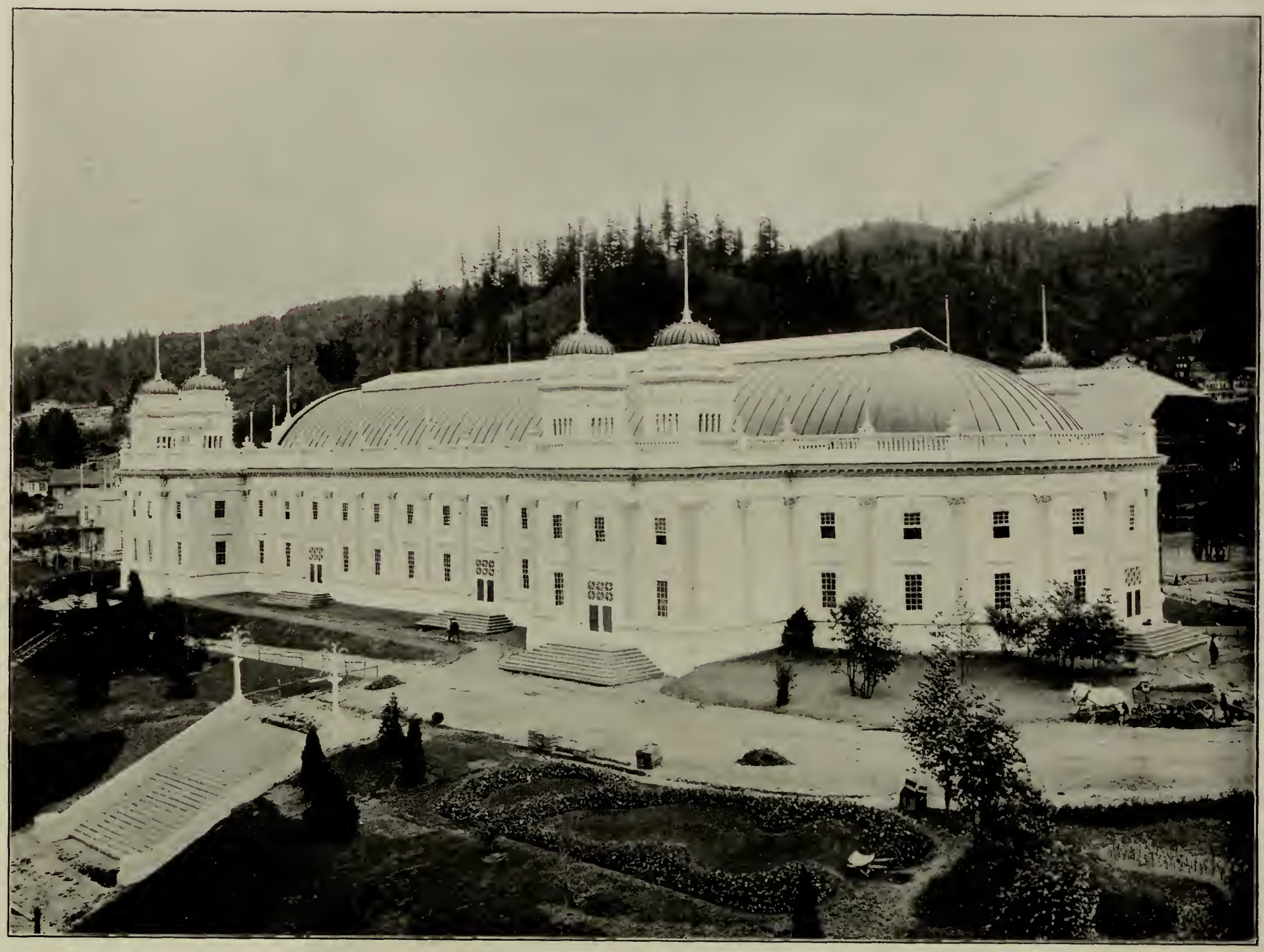

ORIENTAL EXHIBITS PALACE

This Palace stands upon a terrace ncxt east of Forestry Building. It is 150 fect wide and 260 fcet long, and is an exceedingly handsonic structure. The architect is Emil Schacht, of Portland. The Japanese exhibit is very extensive and occupics a very large portion of the floor space. There is a fine display of mantuactures from Persia, Turkey, East India, Egypt and other countrics. An cxtcnsive exhibit of the educational institntions of Orcgon is installed in the famous institutions of our country. Other lines of work of similar nature are shown among the exlibits in the educational section, $111 \mathrm{n}$ y of the oldest annl n110st 


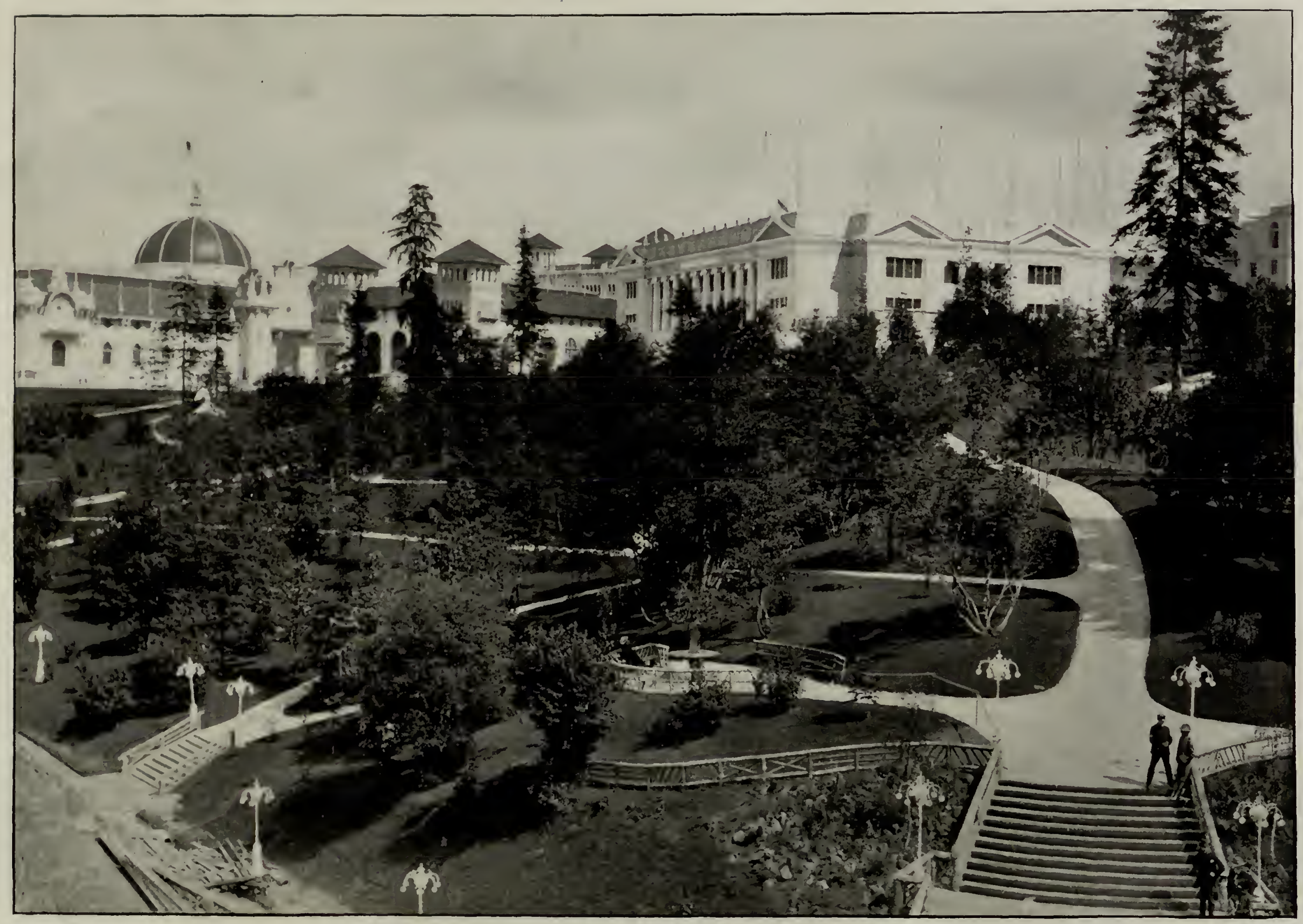

PORTION OF CENTENNIAL PARK

Centennial Park is the wooled portion of the Exposition grounds where the weary visitor turns for rest both for body and brain. The fir trees, with thick foliage, give grateful slade, and the well-kept lawns are restful to the eye. Many seats are placed about in suitable places to invite a respite from sight-seeing. Covering a high, rolling hill the park is nearly always fanned by gentle breezes, Such a boon is Centennial Park for the public that it will undoubterlly be gratefully renembered by hund reds of visitors to the Exposition of 1905 . 


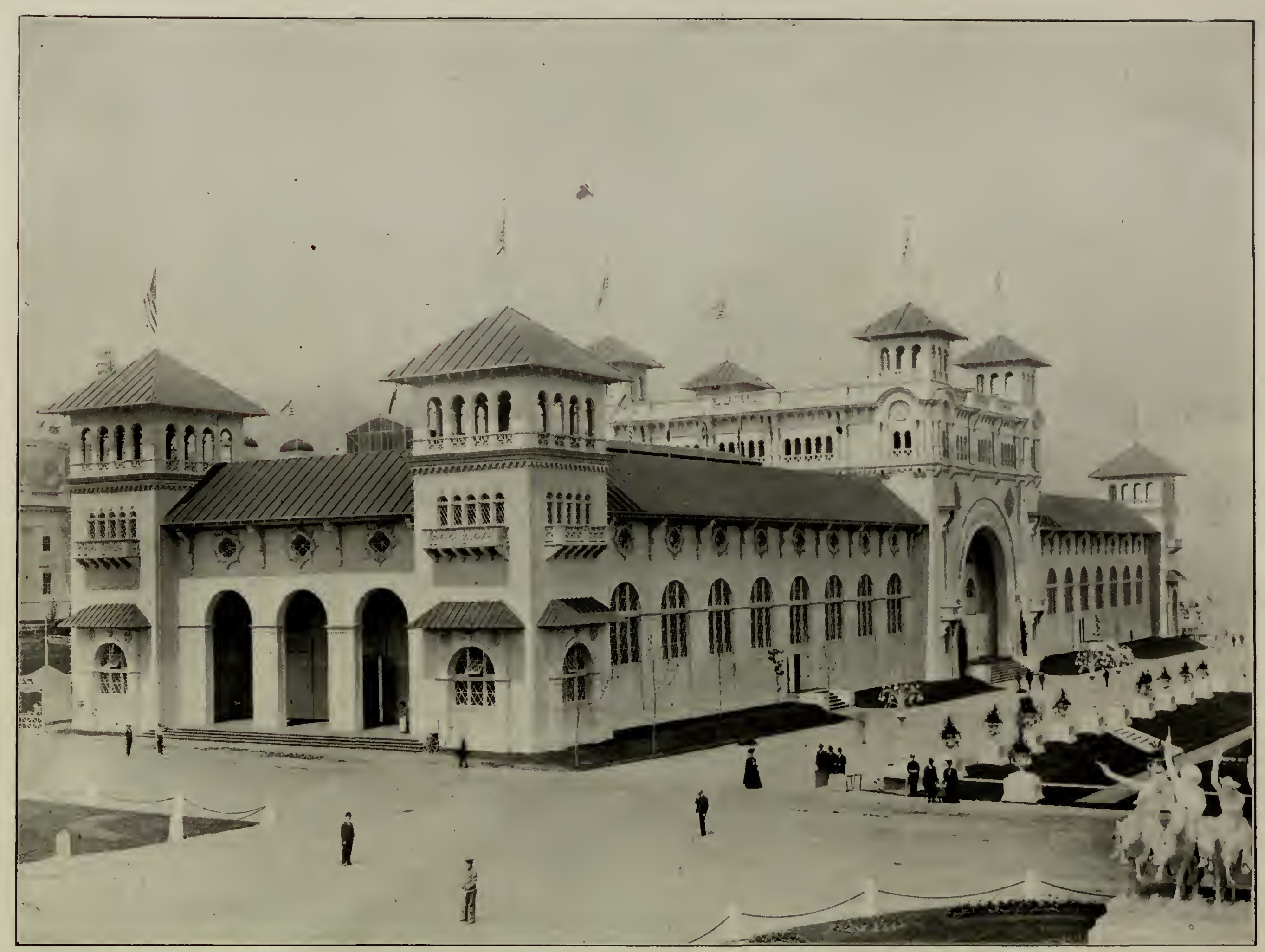

THE FOREIGN EXHIBITS BUILDING

The Foreign Exhibits Building fronts lengthwise on Colunbia Court and the Sunken Garclens. Situated thus proniniently in the Exposition gronp, naturally it is one of the show buildings-one of the most beantiful. It is 100 feet wide and 450 feet long, and is the work of Architect D. C. Lewis, of Portland Fere les british

they explain the nature and vahue of the productions of their country's characteristic ind ust ries. 


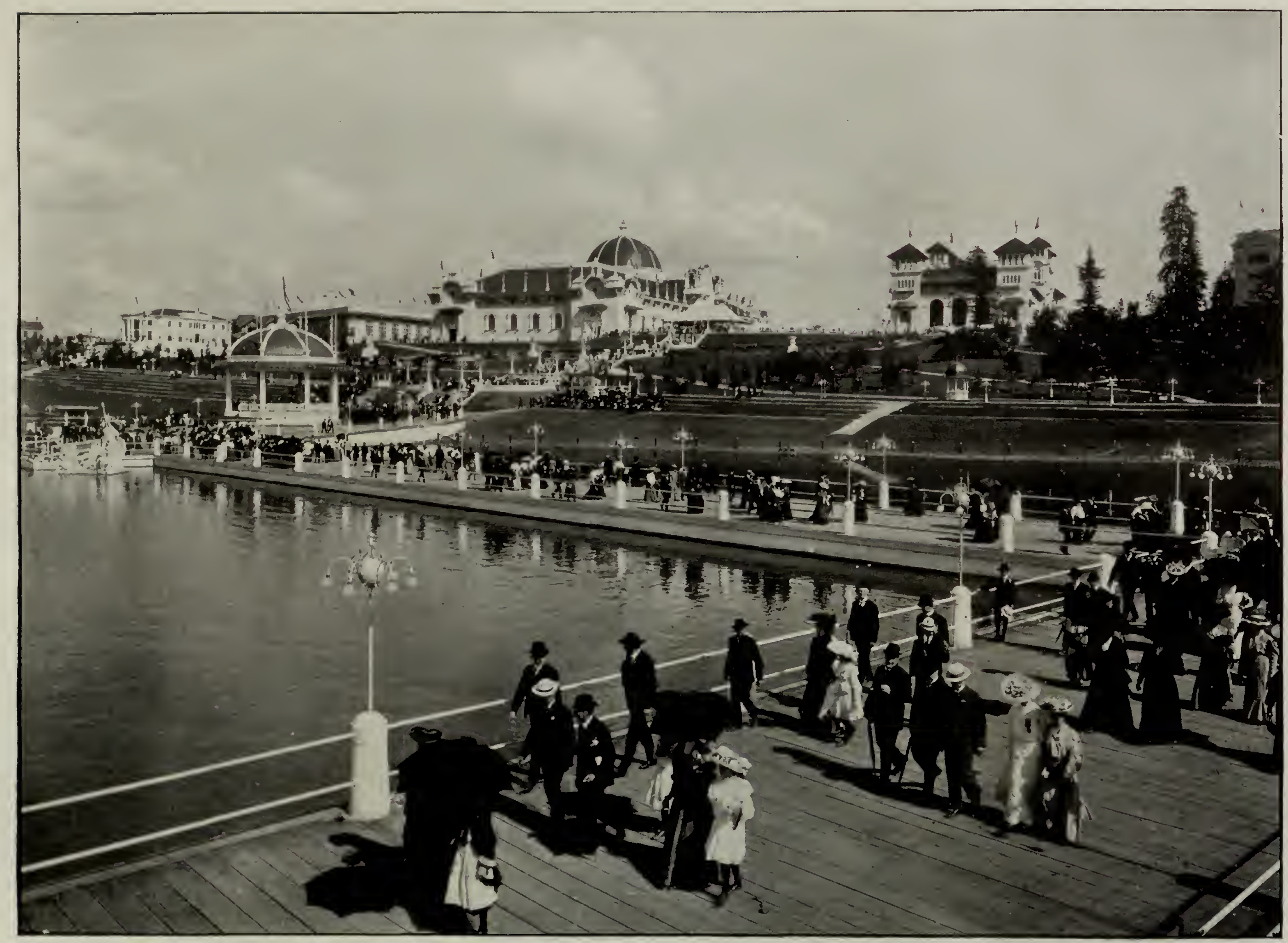

LOOKING TOWARDS EXHIBIT PALACES FROM ESPLANADE

This is one of the most beantiful views of the Exposition. The Esplanade connects the Grand Stairway and the Band Stand with the Bridge of Nations ruming along and part way aronnd Guild Lake. It is one of the popular thoroughfares. From the Esplanade may be seen the Rose Gardens, the Grand Stairway, Oriental Exhibits and Agricultural Buildings, with Manufactures and several of the State Buildings in the distance. At the water's edge is the Band of the Exposition festoons the seene with rowing radiant lights. 


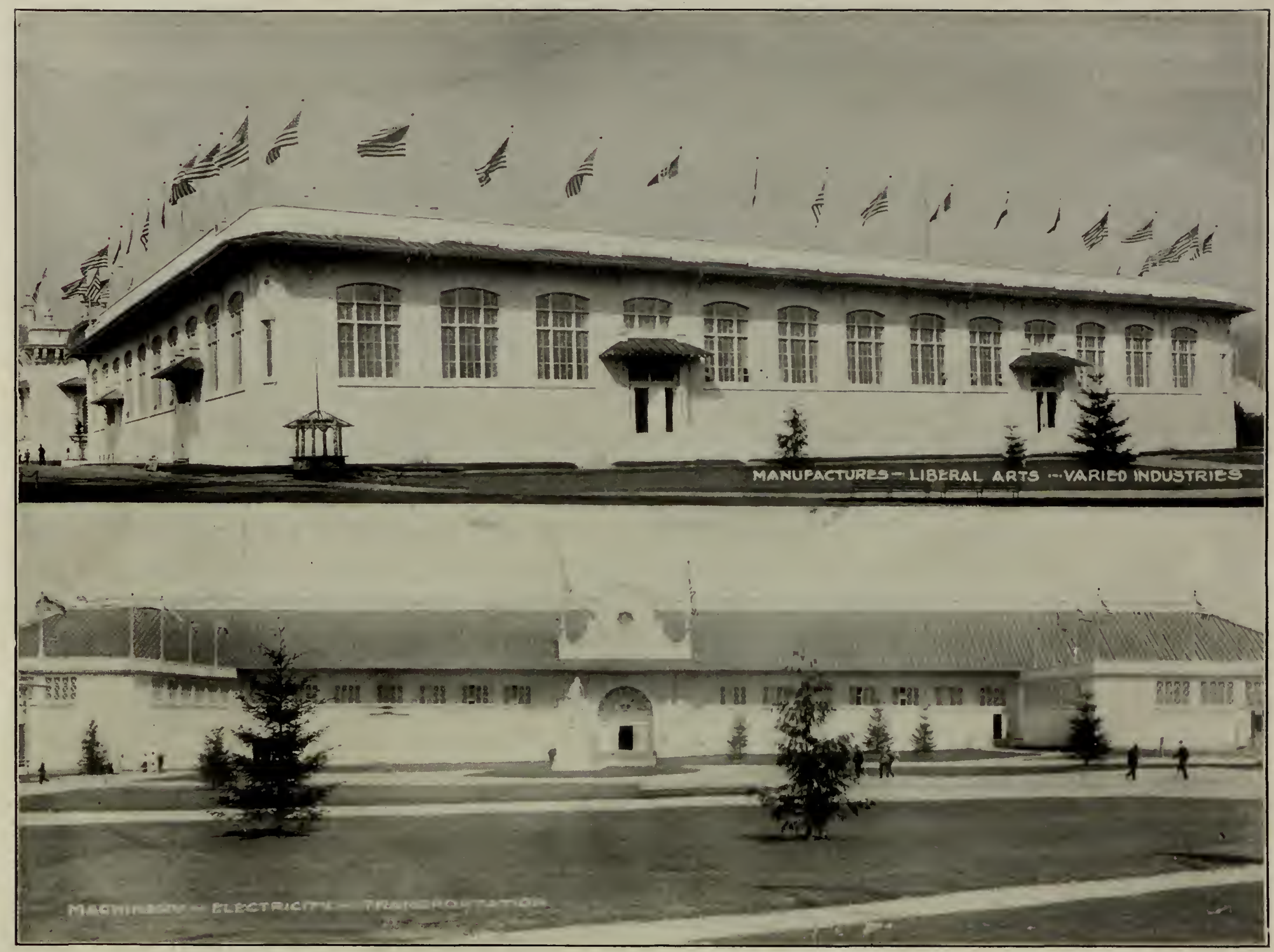

MANUFACTURES, VARIED INDUSTRIES, LIBERAL ARTS-MACHINERY, ELECTRICITY, TRANSPORTATION

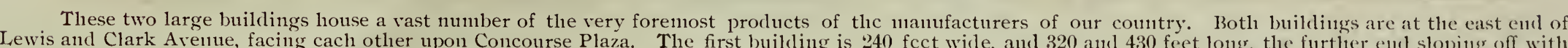
the avenue upon which it faces. Many lines of Lewis and Clark to the Pacific shorc. Machiners, Electricity and Transportation Buil(ning was erected with special reference to the diversificel exhibits to be housed. The main structure is $100 \times 500$ feet with wings at each end $100 \times 100$ feet. Both of these innnense buildings were designed by Ion Lewis, architect, of Portland. In the latter building hours might be spent noting the progress made in the diffcrent departments. In. hotli of these Fixhilibit Palaces Portlant mann-
factures are represented by notable exhibits. 


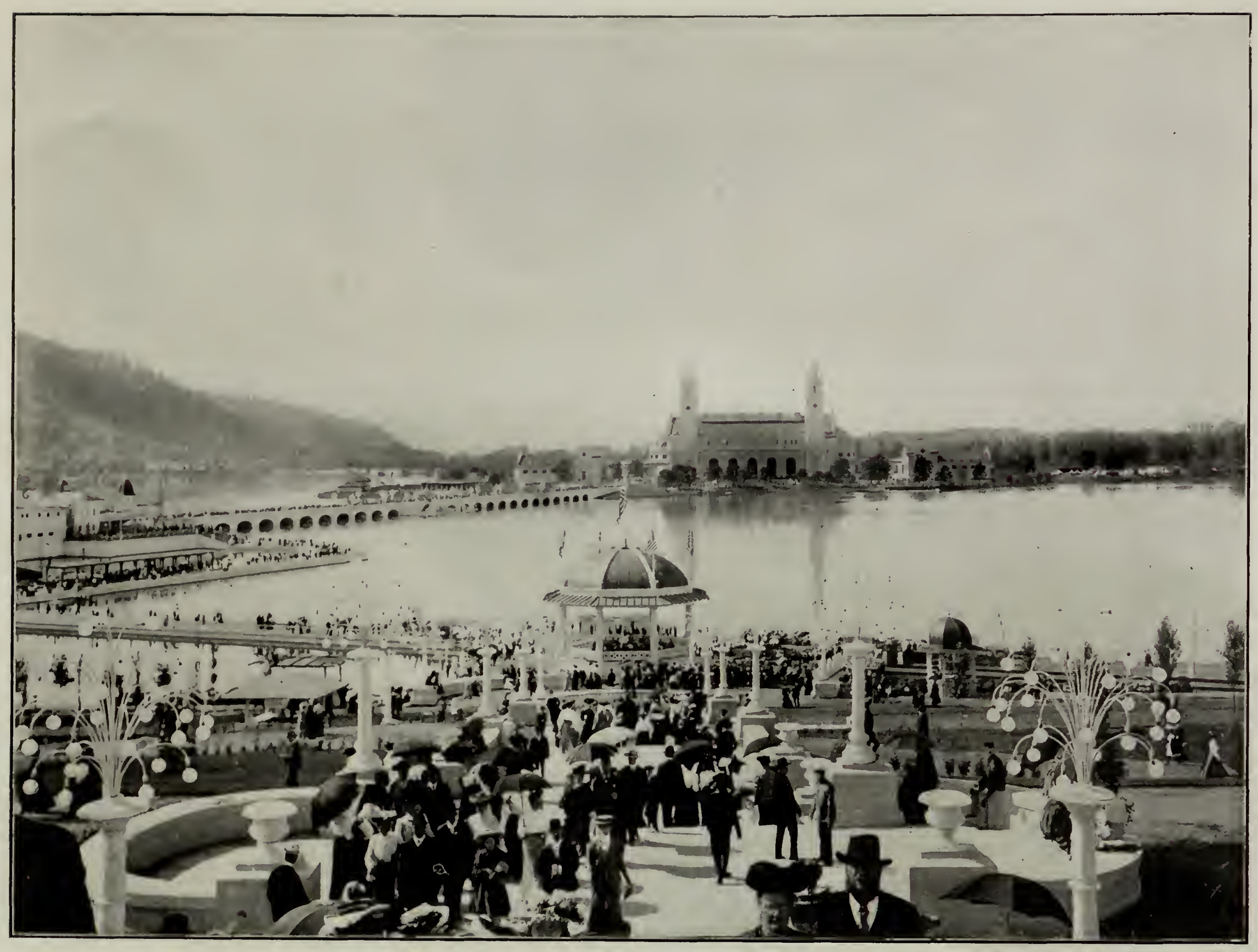

THE GRAND STAIRWAY AND LAKE FRONT

As its name inplies the Grand Stairway is an inposing thoronglifare. In a central location crossing adown the terraces between Lake View Avenue and Guilds Lake front it adds greatly to the picturesque scene. At its foot is the Grand Bandstand, and it is the approas travel to the Bridge of Nations and Govennit Bniling. Fron the Lake Front, below the Grand Stairway, is the landing for the boats which are at the service of visitors, or which ply the lake and land passengers at the Government Building. This is by far the easiest and most agreeable way of reaching that 


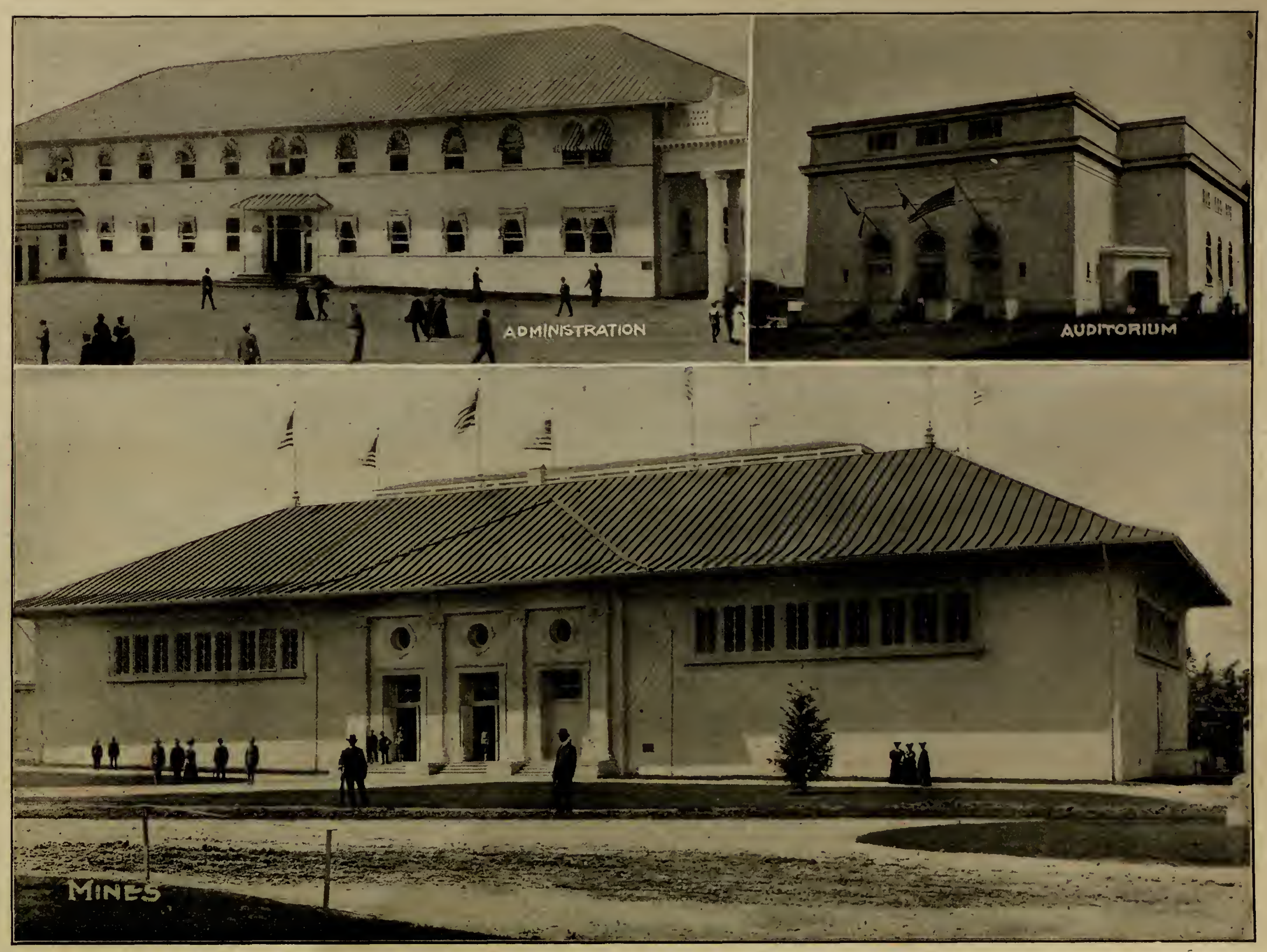

A GROUP OF EXPOSITION BUILDINGS

The Mines and Metallurgy Building faces upon Concoursc Plaza between the two grcat palaces Manufactures, Liberal Arts and Varied Ind ustries and Maehinery, Electricity and Transportation. There are fine displays of all the metals, preeious and coarse, found in the State of Oregont and thic ad jacent territory. Coal, whiel must some day be one of the most valuable of the mining products in this section, has sevcral fine spceincns shown. The building is $100 \mathrm{x} 200$ fcct. The Aud 1 torium is located opposite the Mines across Concourse Plaza. It has a seating eapacity of 2,500. The Administration Building, containing the cxecutive offiees of the Exposition, is at the left of the grounds between the entranee turnstiles and the more elaborate Colonnade entrance. 



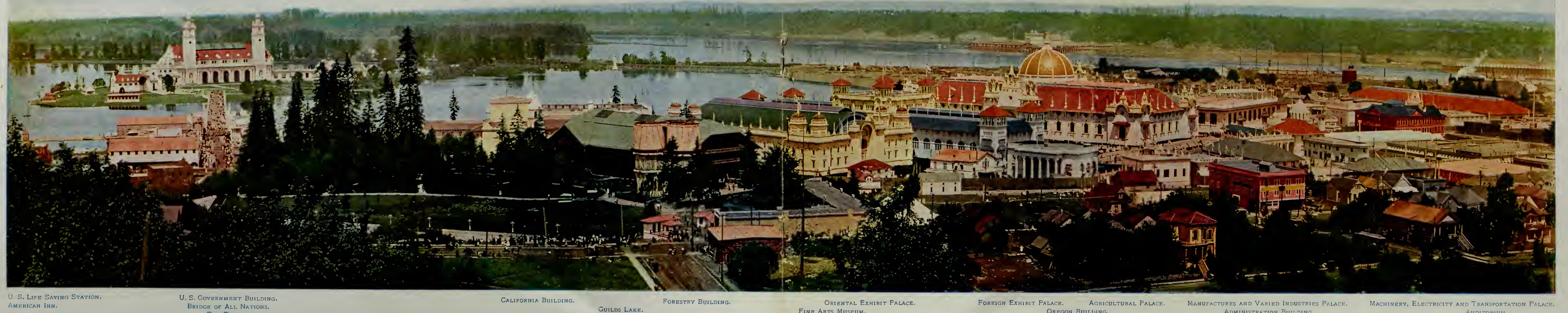




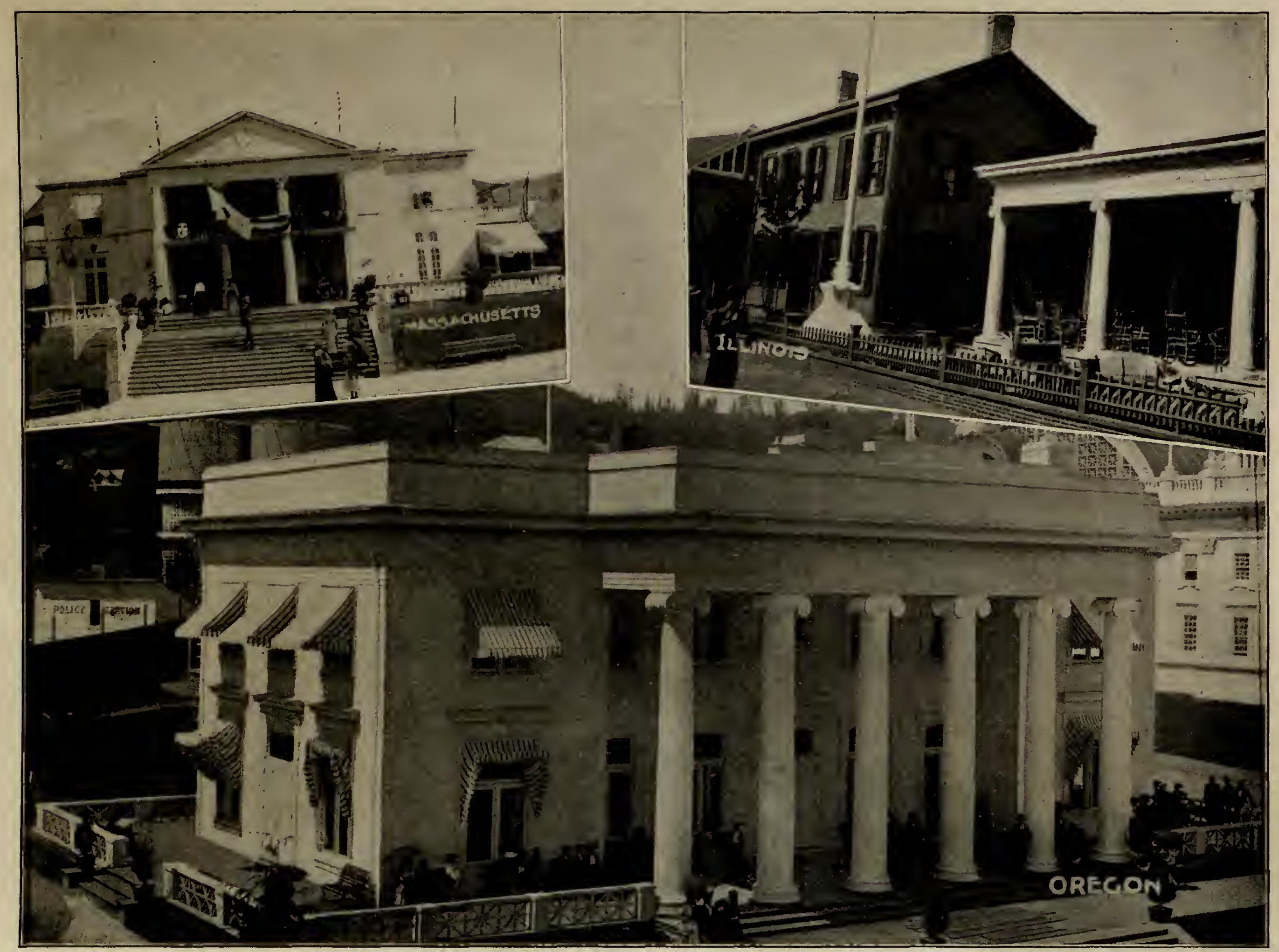

STATE BUILDINGS

The Oregon State Building is used almost wholly for social purposes, the exhibits of the State being found in extensive scope in all the great Exhibit Palaces. This finc building is at the left as onc passes through the Colonnade entrance. Here the people of Oregon congregate for a renewal of friendship and to greet al comers. The Massachsetts Statc Bunthing is eminently an expression of good will by the people of that grand old conmonivealth. It is filled with Educational welcome ancl interesting to the Anerican public could have been presented by the people of Inlinois. 


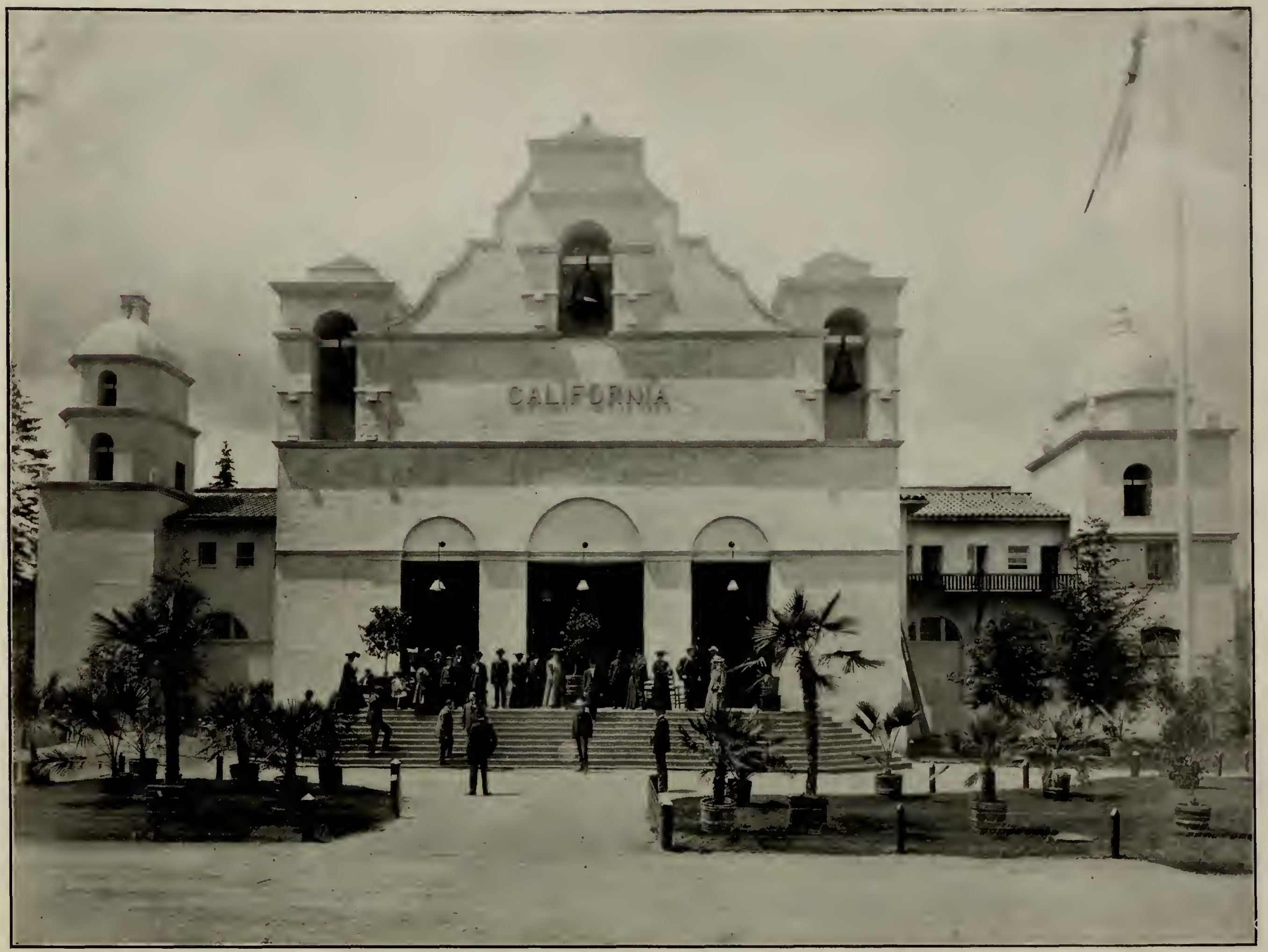

THE CALIFORNIA STATE BUILDING

The citizens of that wonderful state, California, are ever enterprising and abreast of the tinnes. At the Lewis and Clark Exposition no otler state snrpasses their splendid representation. The appropriation for this purpose was $\$ 90,000$. The building is in the shape of a Greek cross, the four fronts of which are replical

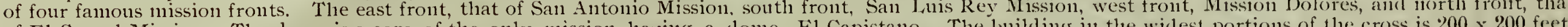
of El Carnel Mission. The dome is a copy of the only mission having a done, El Capistano. The lut R and it has 43,00 feet of The space. The the vistor. her display. 


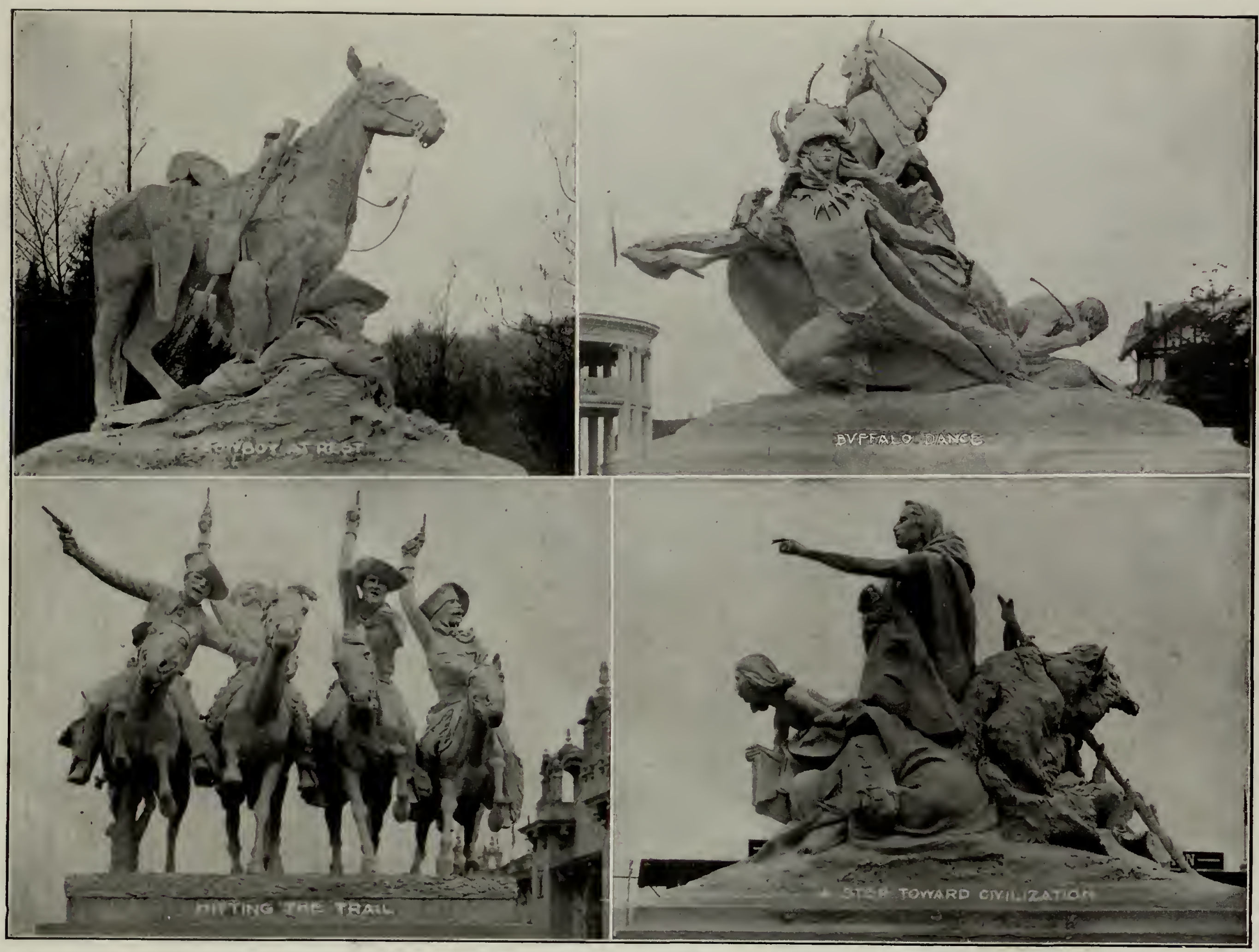

SOME OF THE STATUARY ADORNING THE GROUNDS

Very inpressive and inspiring are the groups of statuary erected about the Exposition grounds. HrTTING THE TRAIL is a stirring group by Frederick Renington, representing cowboys out for sport anil engaged in "shooting up the town." "It stands just within colonnade entrance on Lewis and Clark avenue. TIIf BUFFA DANCF, is a notable scuipture by Solon H. Borghum, portraying a favorite Indian pastime. It stands near the New York State Building. A STEP TowARis CTinzatron is a group located on Conconrse Plaza which symbolizes advancement of the Red Man-turning from the rude dress, the skins of animals,

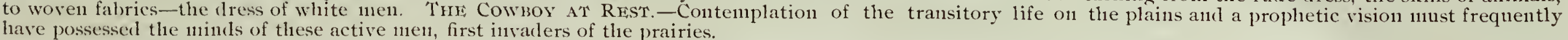




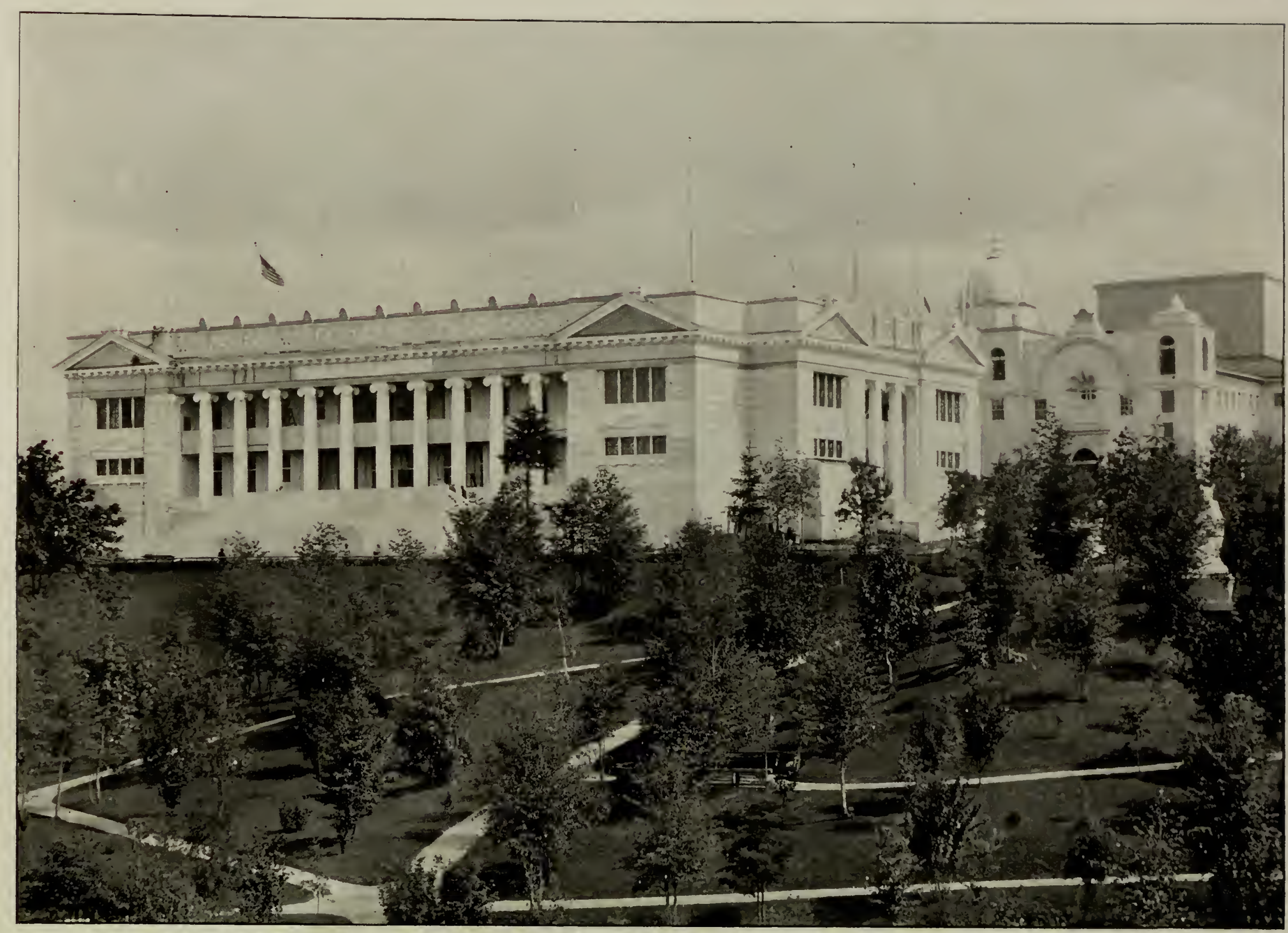

WASHINGTON STATE BUILDING

The Washington State Building has a queenly site fronting upon Centennial Park overlooking the Grand Stairway, the Terraces and the Lake Front. It is both beautiful and impressive. On all sides rows of Corinthian pillars support the roof. The building is $130 \mathrm{x} 1: 0 \mathrm{fee}$. The state appropriation was $\$ 92,000$, showing that the people of that State appreciated fully the importance of the event celebrated by the Exposition and the great opportunity it would afforil the world to learn of her inexhaustible resources. The building houses an exposition in itself-so widle, varied and complete are its exhilits. 

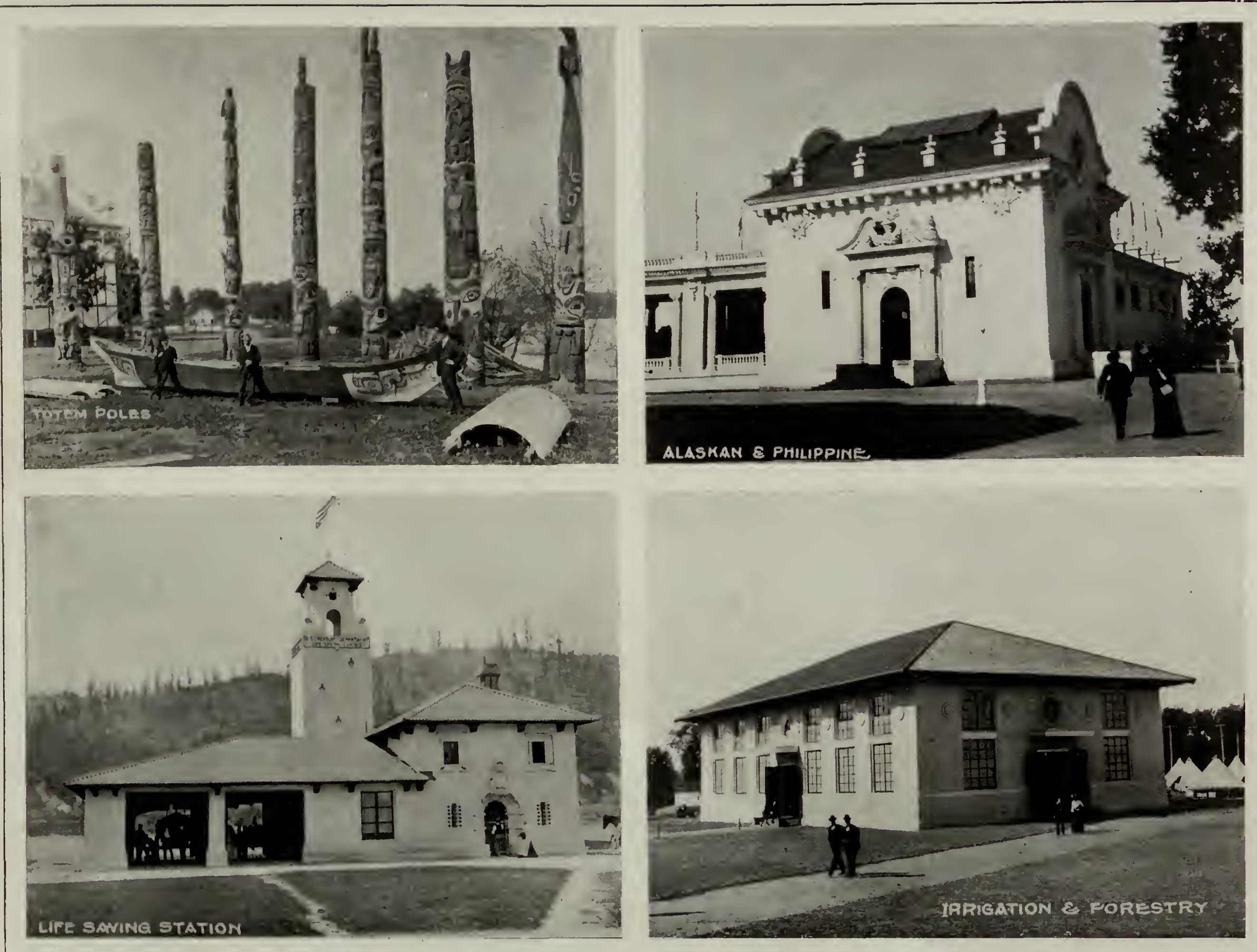

ATTRACTIONS SURROUNDING GOVERNMENT BUILDING

The group of Totem Poles stand near the east wing of the Government Building. The carvings upon then represent some important family event, or some special historical date, according to the purposes of the totem. A correct knowledge of their significance is an interesting study. THE IRRIGATION AND FORESTRY EXH1BIT BUI,DN, is at the rear of the east colonnade of the Governnent Building. It contains extensive exhibits of these in1portant subjects. THE UNITED

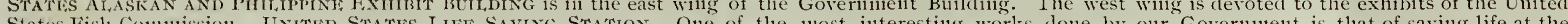
dam1serons points upont the Coast. The daily exhibits given show how hundreds of lives are saved anlunally. 


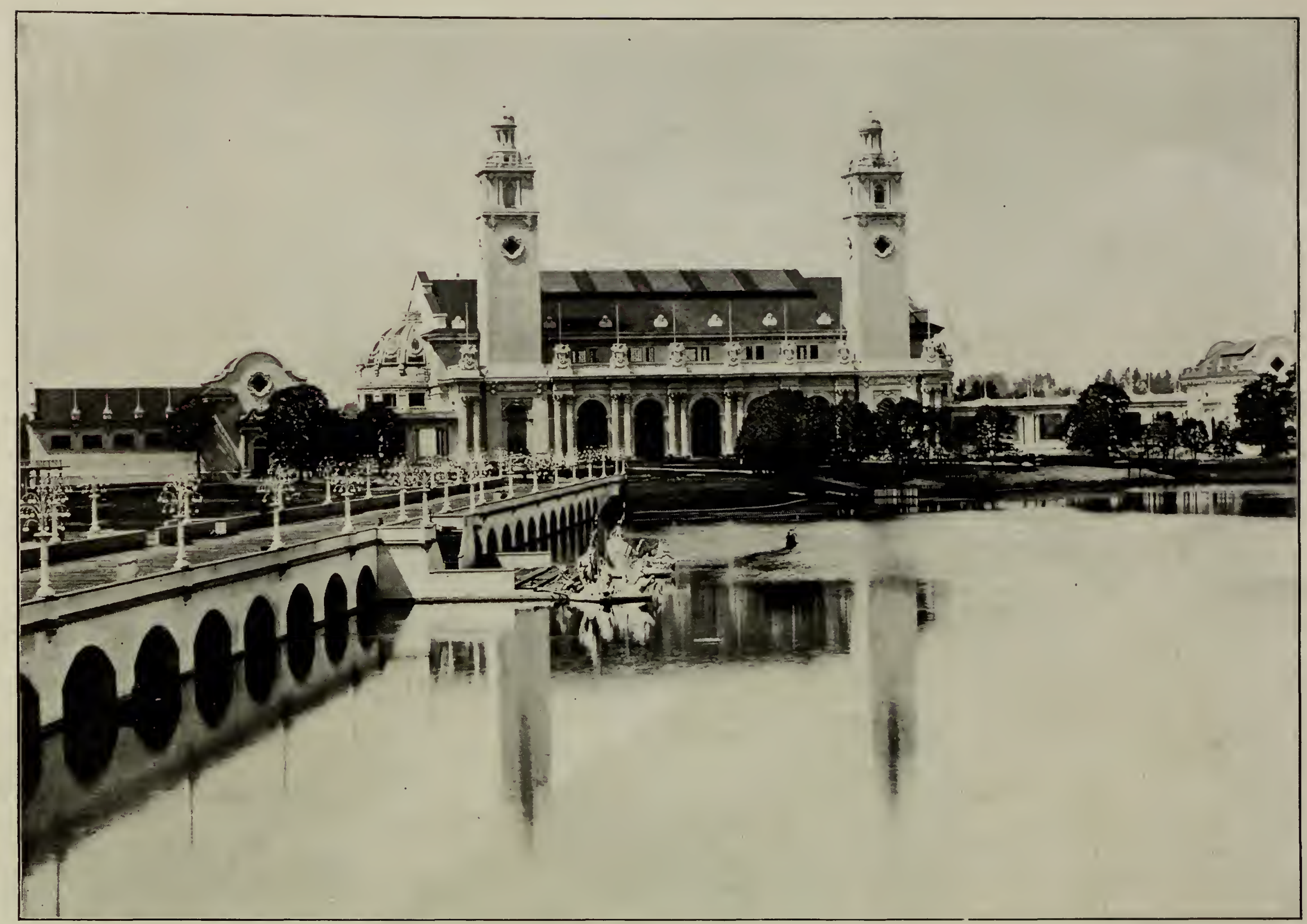

UNITED STATES GOVERNMENT BUILDING

It has been the custom of our gorernment to participate generously in all inportant expositions. The governnent builling at the exposition of 1905 is the largest of any exhibit building upon the grounds. It was designed by Jas. Knox 'Taylor, of Washington, D. C., the governnent architect. It consists of a ninin central structure $176 \times 425$ feet, connected on either end by semi-circular colonnades, each $34 \times 200$ feet, with buildings which are 100$) \times 100$ feet, the whole forming a frontage of 1025 feet. The building nearest the Bridge of Nations is occupied by the Fish Commission, which lias nuany large tanks stocked with living specincens. The other end building contains the esoremment's Alaskan and Philippine exhibits. The War Departnent, the Post Office Departinent, the Bureans of Agriculture and of Mining, Treasury and other departments are in the main building. Back of the right lianl colonnale is the building contaning the Irrigation and Forestry exhibits. Near the Bridge of Nations is the Life-Saring Station, where daily drills are griven by the life-saving crews. 


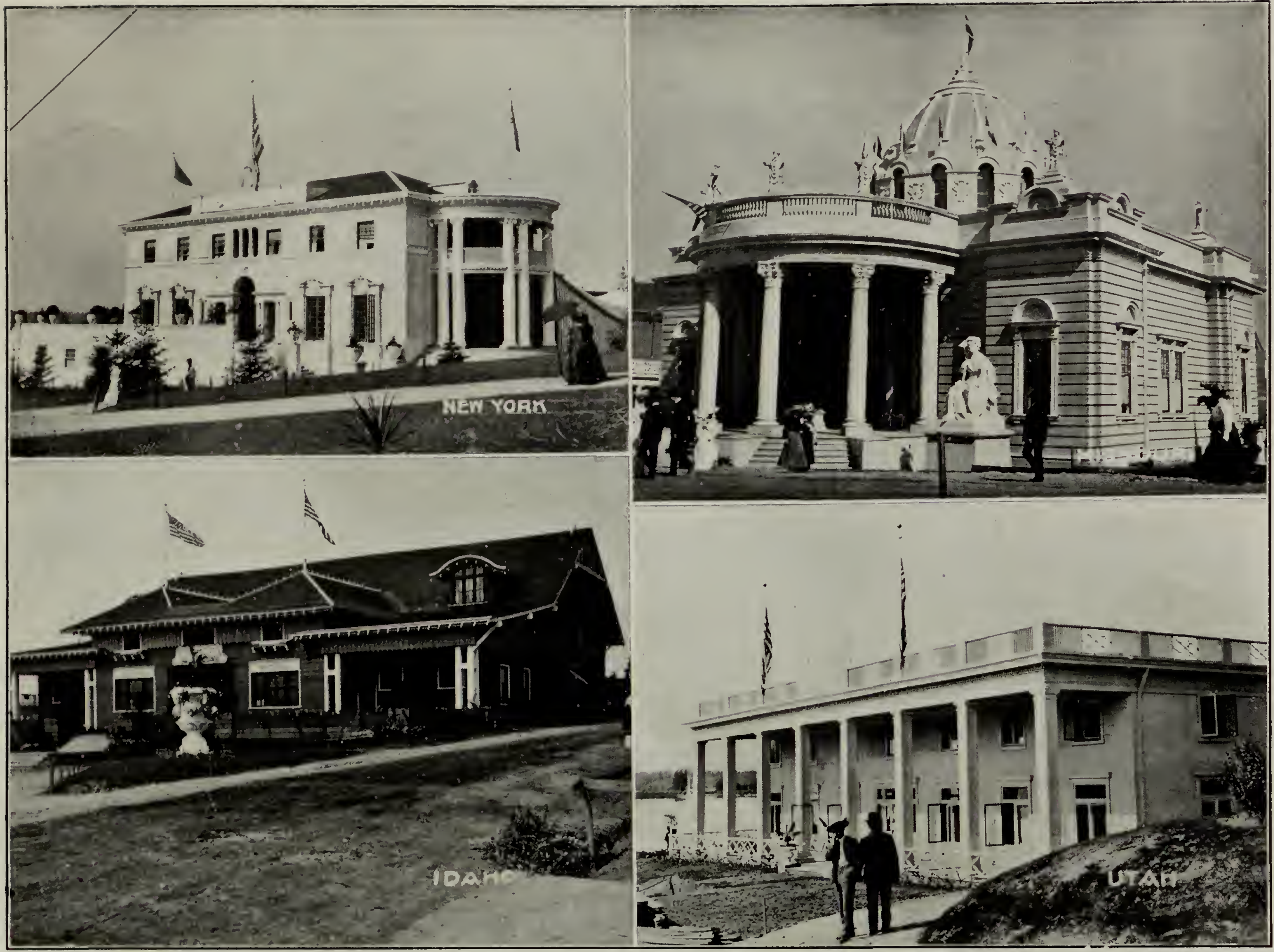

STATE BUILDINGS

The building erected by the State of New York is one of the most beantiful structures upon the grounds. It is an architectural gem. Ornanented with innumerable vases of flowering plants, which add color to its white walls, it is admired by all. The IDAHo BuInDING standing to the right and beyond the New York Building is a conmolious, handsome structure adding greatly to the beauty of the scene. It is well filled with exlibits from the State, all arranged in a most artistic manner. The UTAF BUIDDNG occupies the eminence overlooking Guilds Lake just beyond the Itaho Building. It is an impressive structure having its roof supported by a number of pillars, which adds to it an air of elegance. The building is an expression of the enterprise of the people of that great State. The also las an art gallery, witl a special display of pictures by Missouri artists. 


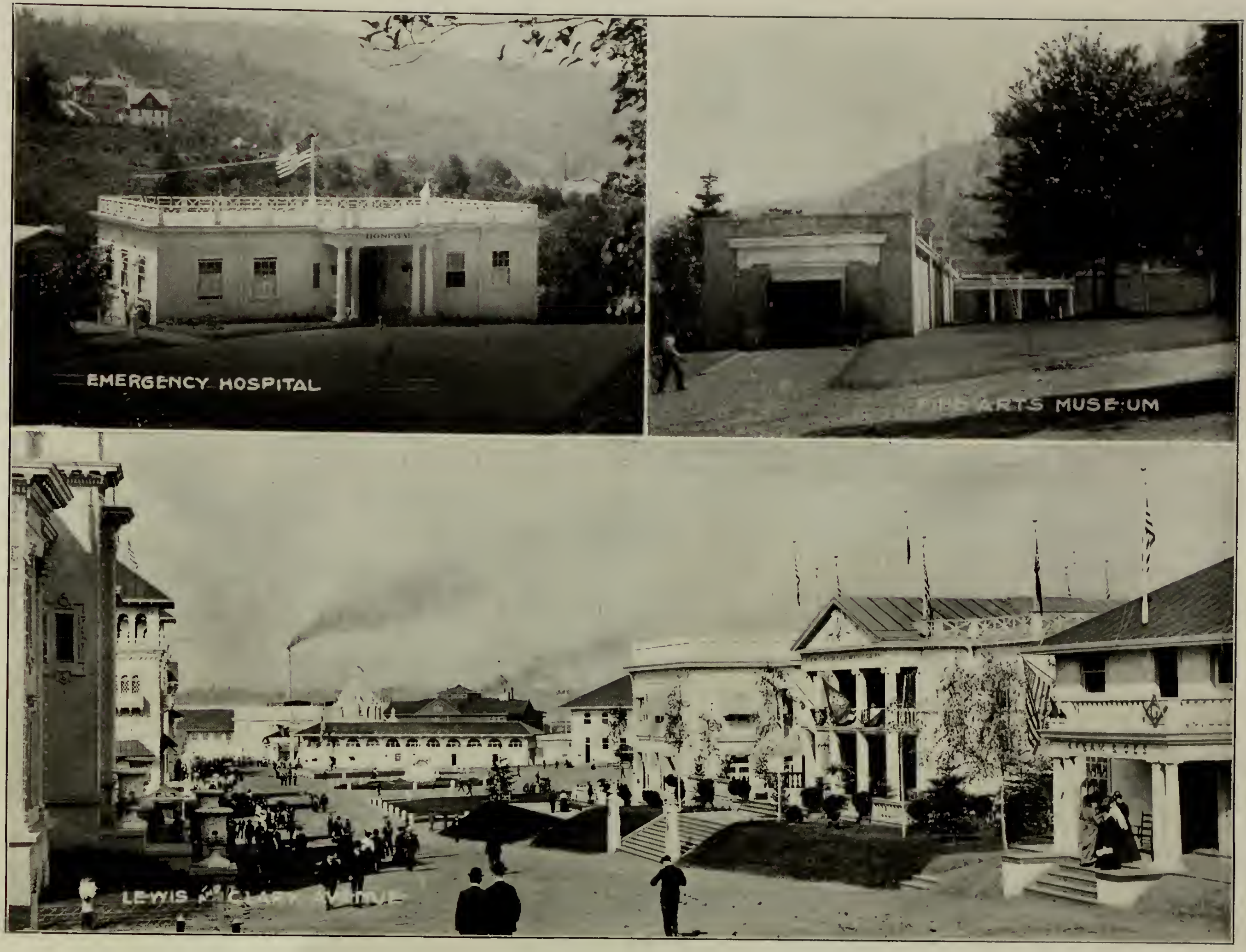

LEWIS AND CLARK AVENUE

Lewis and Clark Arenue is the principal thoroughfare run11ing east and west. It is just within the Colonnalle entranee. The Art Museun is at its extrene west end, its eastern terminus being Coneourse Plaza. On the right as pictured above is the Masonie Building, and 11ext, the Massichnsetts State Building; the

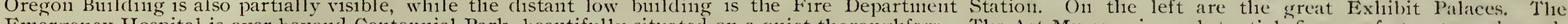

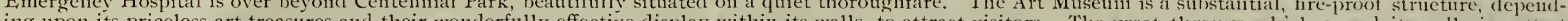
(lits galleries attest Museu11. 


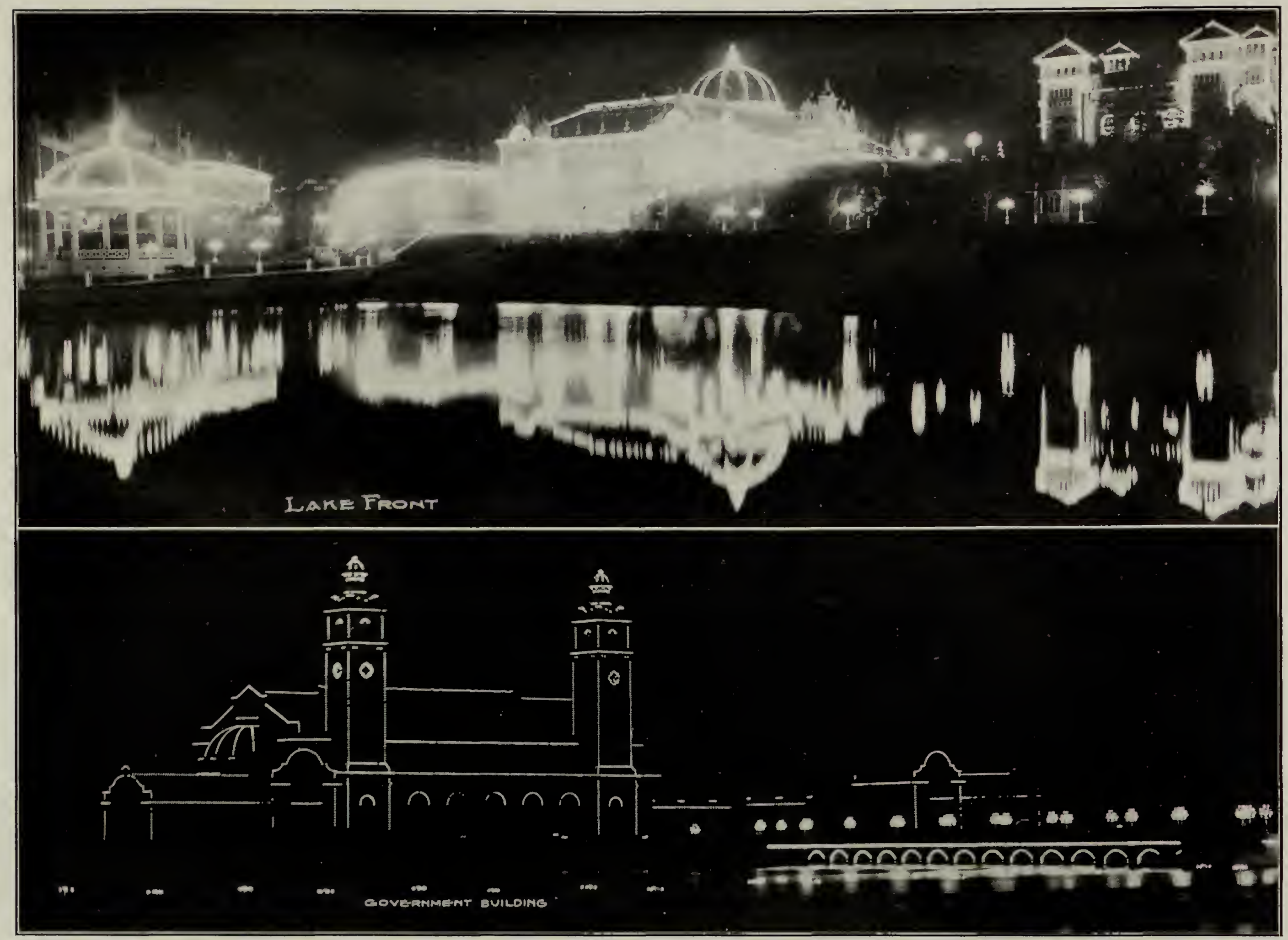

THE EXPOSITION AT NIGHT Night works a transformation at the lair. Every graceful line and curve is softened, every mass of color is subdued, everything is under the witchery of
the effulgence produced lyy uncomted lights. The scene is beautiful by day, but at night it is another picture and an entrancing one. The lights steal gently forth, frst with a dull glow, then more boldly, until at last every great building, and statue, and bridge, is outlined and festooned with countless glowing points

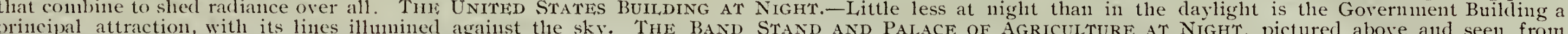
the Bridge of Nations, is a part of a glorious picture. The outlines are duplicated in the mirror of the lake, where they sway and palpitate as the water is agitated or rippled by the gondoliers' oar. 


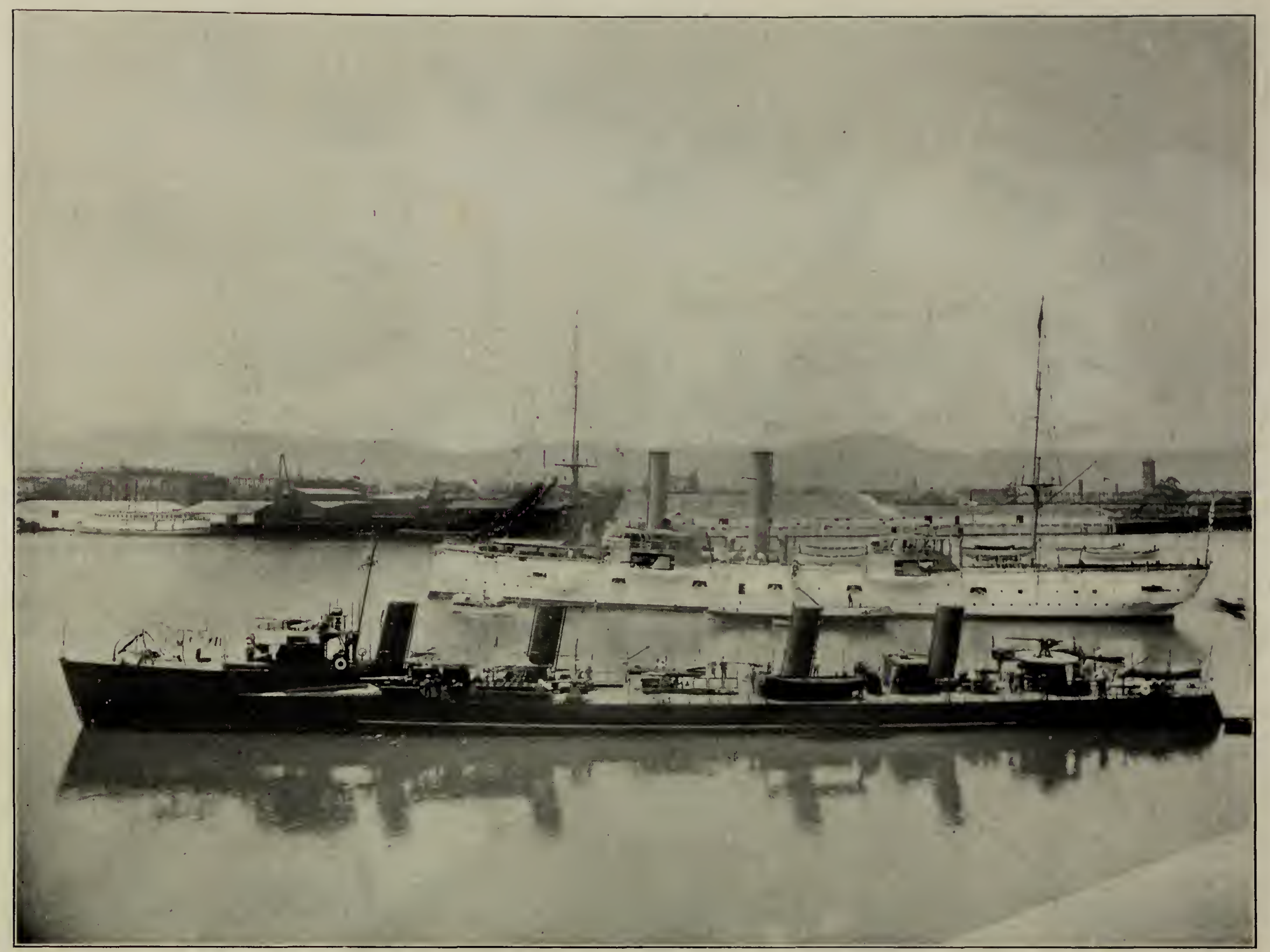

PORTLAND HARBOR

This picture shows the presenee in Portland Harbor of two of the Ameriean naval ressels, the Protected Cruiser Chicago, 18 gmms, flagsliip of Rear Admiral Caspar F. Goodrich, commander-in-ehief of the Pacifie Squadron and Torpedo Boat Destroyer Perry, Frank H. Schofield, connmander. Visits of the slips of our navy are always interesting events, and have been espeeially so during the Exposition when so many people have heen able to view then who do not often have the opportunity. Portland is fortunate in her harbor. Deep sea going vessels sail up the Columbia and the Willantette, the greatest tributary to the Columbia, to Portland harbor and noor at the wharves. There they unload, load and reaeh the Paeifie Oeean withont lightering and without delay. The greatMany exeursion and pleasure eraft rendevous in the harbor and ply the rivers. 


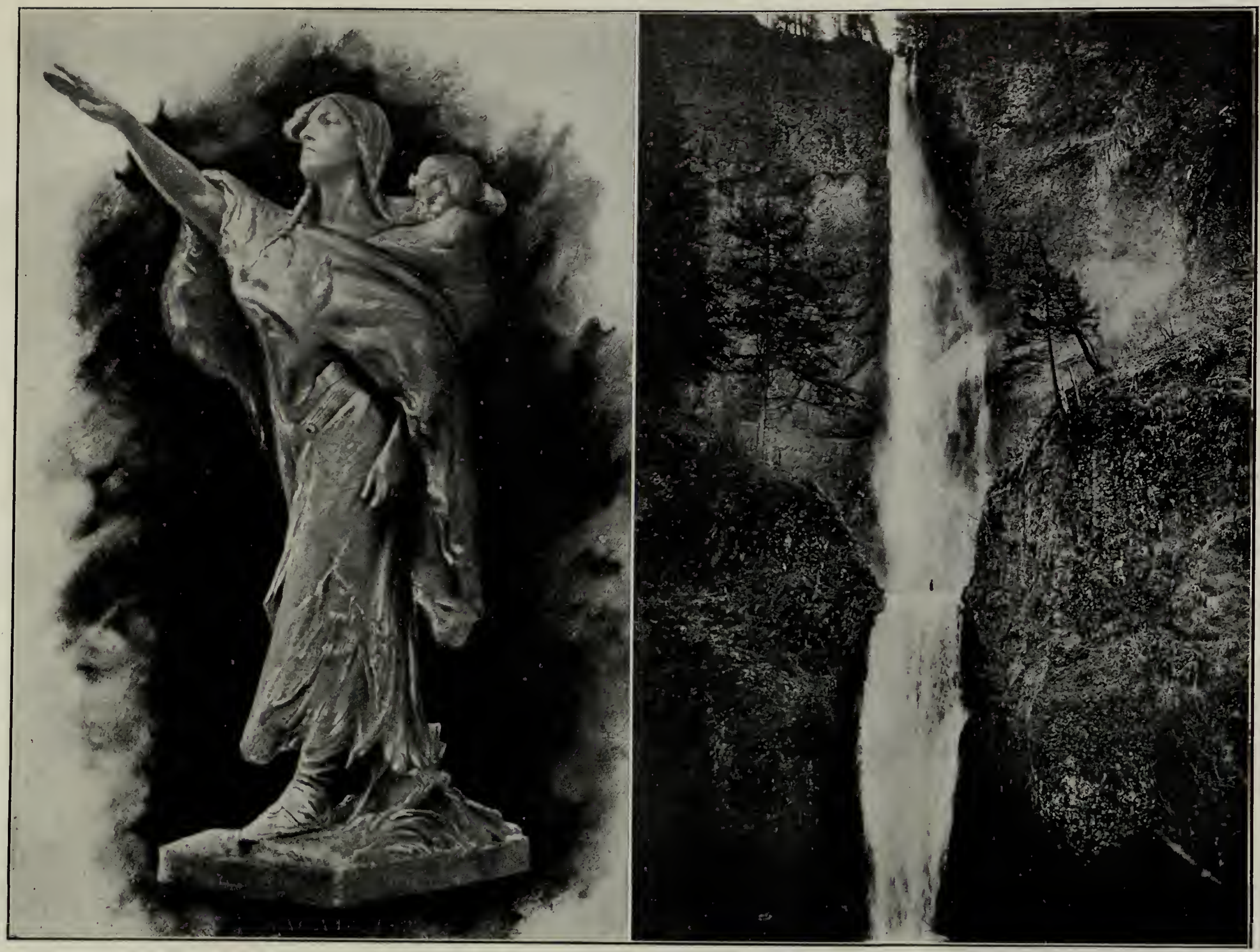

STATUE of SACAJAWEA (BIRDWOMAN)

MULTNOMAH FALLS

"Sacajawea guided Lewis and Clark across the Coast Mountains and pointed out the Trail when every hope of ever seeing the ocean seemed gone. When she jonted the Lewis and Clark expedition in 1804 , in the Rocky Mountan region, it was as the slave wife of Charbonneau, a French-Canadian voyagenr and interpreter. It happened that Sacajawea was a Shoshone Indian who had been taken captive by the Blackfeet and her youthful days had been spent in the country Sacajawea displayed herself to be possessed of high virtues. She kncw not fear and exhibited daring on many occasions. The statne is ant idealized cienting It was designed by Miss Alice Cooper, of Denver. It was cast by Bonard, in copper, from Oregon mines, given for the purpose The funds for counte of the montunent were raised through the efforts of patriotic women of Portland. Falling 840 feet Multnomah is the highest, most beautiful and renowned of the Columbian Falls. It is 32 niles distant from Portland, up the Columbia. 


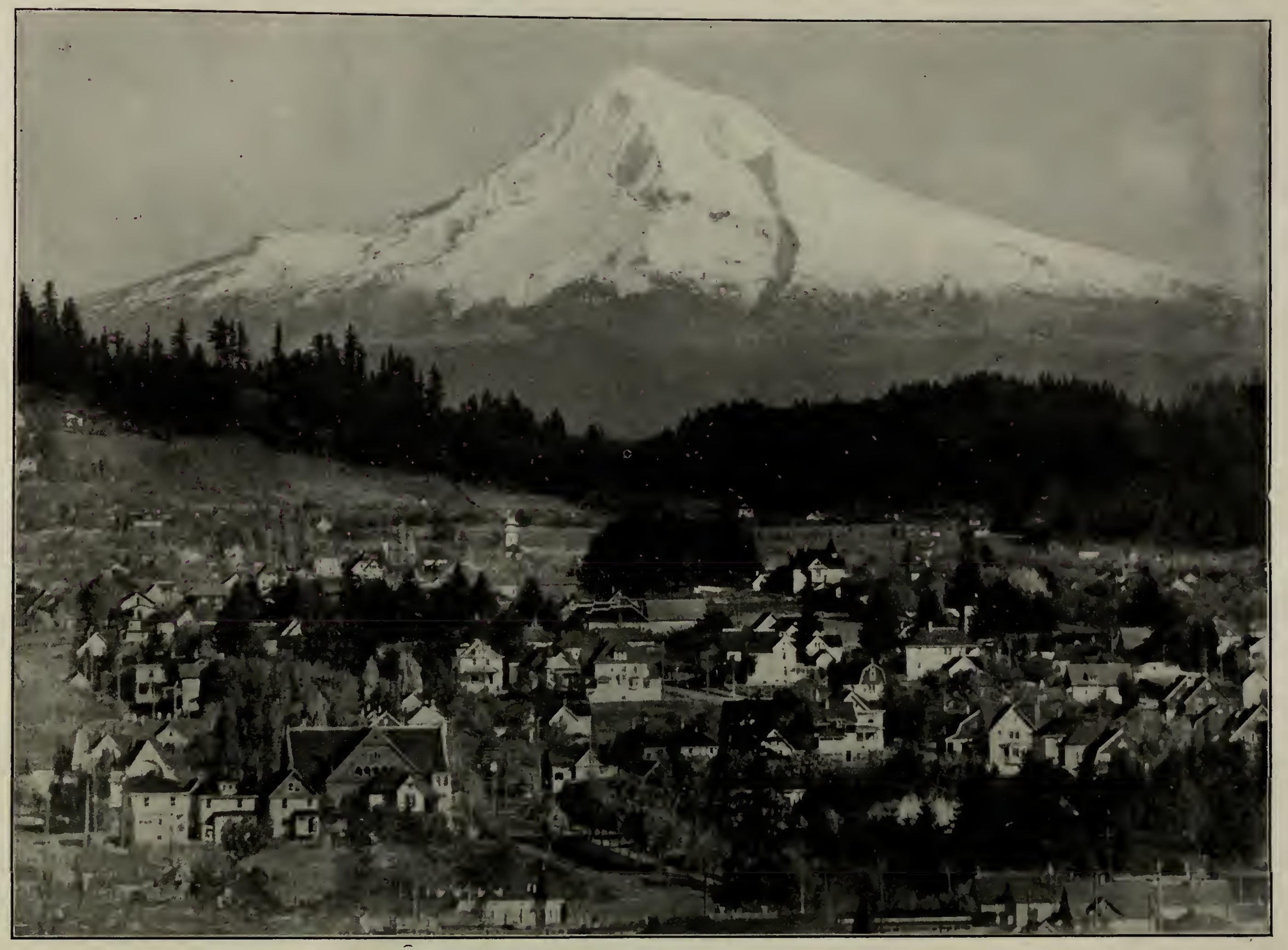

COPYRIGHT 1905, BY F. H. BHOGREN

SNOW-CAPPED MT. HOOD, SEEN ACROSS THE EXPOSITION CITY

Not every day may Mt. Hood be seen at its best, for elouds ever hover 'round it, but the eonstant wateher is frequently rewarded by' seeing it stand forth Pot every day may Mt. Hood be seen at its best, "Fifty mililes east of Portland by air line and ninety-three by shortest route, this favorite proully rears its hed rears its head 11,225 feet heavenward, then whe to Lewis and Clark on their memorable trip of "explo* * * Looking from the summit "to the north sixty miles is Mount Arlanis, 12,470 feet liigli be, hundreds elimb to its sume on strete peaks. For miles and miles the inighty Crile valleys."--Rinaldo M. Hall. 


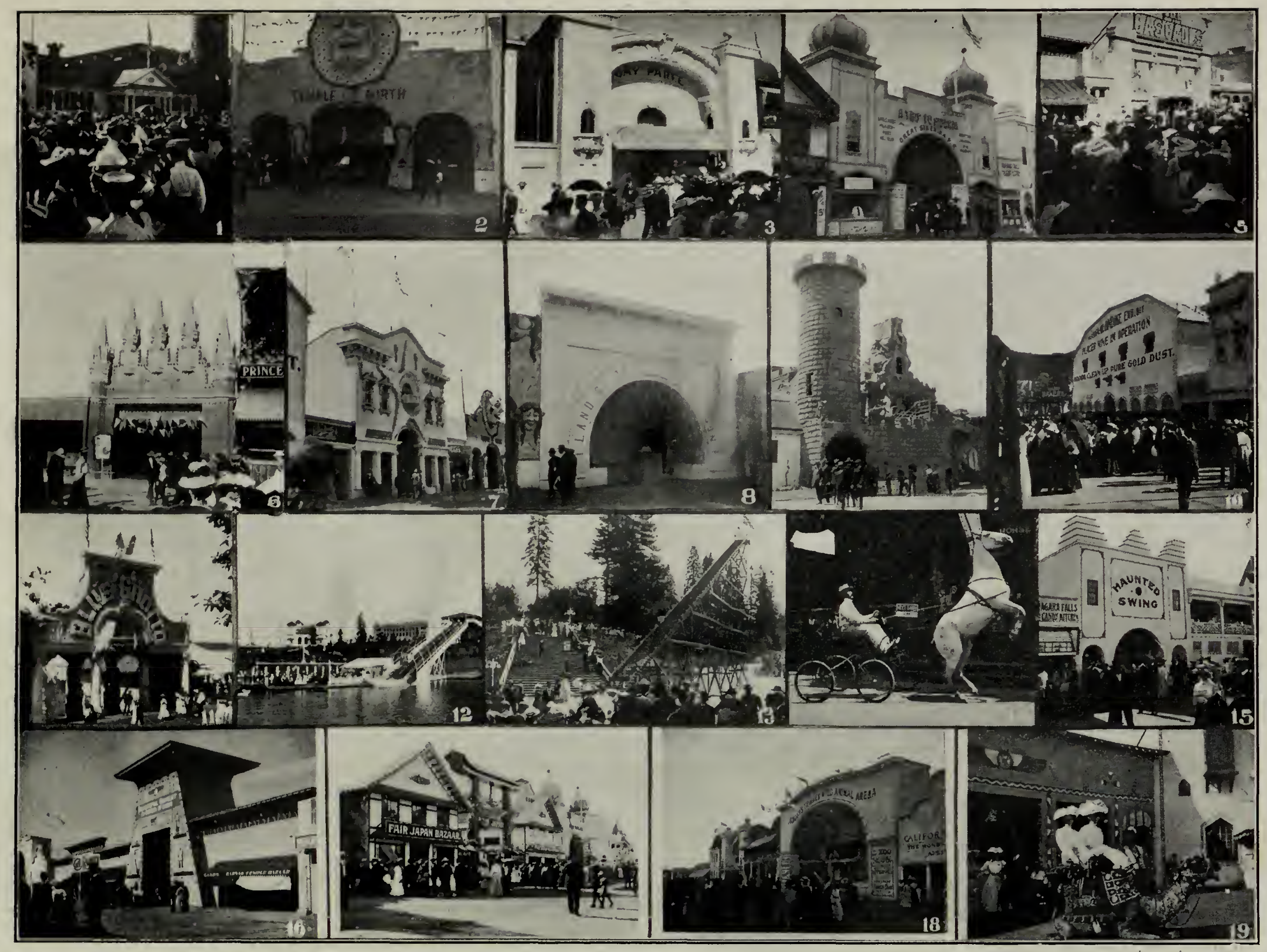

A MEDLEY OF TRAIL ATTRACTIONS

1. The Infant Incubator. 2. The Temple of Mirtl. 3. Gay Paree. 4. A Trip to Siberia. 5. The Cascades. 6. Darkness and Dawn. 7. The Old Plantation. 8. The Iand of the Midninglit Sun. 9. The Trixie, the Educated Horse, and Higli-Diving E1ks, 15. Haunted Swing. 16. Entrance to Cario. 17. Fair Japan. 18. Jabour's Trained Wild Animal Arena. 19. Cannel Riders in Cario. 

